\title{
On trade policies and wage disparity in Egypt: Evidence from microeconomic data
}

Chahir Zaki

Follow this and additional works at: https://knowledgecommons.popcouncil.org/departments_sbsr-pgy

Part of the Demography, Population, and Ecology Commons, Family, Life Course, and Society Commons, International Public Health Commons, and the Labor Economics Commons How does access to this work benefit you? Let us know!

\section{Recommended Citation}

Zaki, Chahir. 2011. "On trade policies and wage disparity in Egypt: Evidence from microeconomic data," Gender and Work in the MENA Region Working Paper no. 15. Cairo: Population Council. 


\section{NUMBER 15}

JUNE 2011

GENDER AND WORK IN THE MENA REGION

WORKING PAPER SERIES

Poverty, Job Quality and Labor Market Dynamics

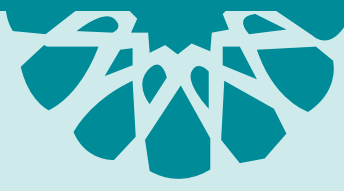

On Trade Policies and Wage Disparity

in Egypt:

Evidence from Microeconomic Data

Chahir Zaki

12 Population Council 
Chahir Zaki is an Assistant Professor, Department of Economics, Faculty of Economics and Political Science, Cairo University, and a Research Associate of the Economic Research Forum, Cairo, Egypt. Email: chahir_zaki@yahoo.com

The research presented in this publication is the result of a project funded by Canada's International Development Research Centre (www.idrc.ca).

\section{IDRC * CRDI}

Canadäa

\section{Population Council \\ Research that makes a difference}

The Population Council confronts critical health and development issues-from stopping the spread of HIV to improving reproductive health and ensuring that young people lead full and productive lives. Through biomedical, social science and public health research in 50 countries, the Council works with our partners to deliver solutions that lead to more effective policies, programs, and technologies to improve lives worldwide. Established in 1952 and headquartered in New York, the Council is a nongovernmental, nonprofit organization with an international board of trustees.

Population Council

Egypt Office

59 Misr Helwan Agricultural Road, Maadi, Cairo, Egypt

Tel.: (+202) 2525-5965, (+202) 2525-5967, (+202) 2525-5968

Facsimile: (+202) 2525-5962

Website: http://www.popcouncil.org

Email: pcouncil@popcouncil.org

(C) 2011 The Population Council, Inc.

Any part of this publication may be reproduced without permission for limited distribution, provided it is distributed without charge and the Population Council is acknowledged as its source. The Population Council would appreciate receiving a copy of any materials in which the text is used.

ISSN: 11869/2011 
NUMBER 15

JUNE 2011

GENDER AND WORK IN THE MENA REGION WORKING PAPER SERIES

Poverty, Job Quality and Labor Market Dynamics

\section{On Trade Policies and Wage Disparity}

in Egypt:

Evidence from Microeconomic Data

Chahir Zaki 



\section{Table of contents}

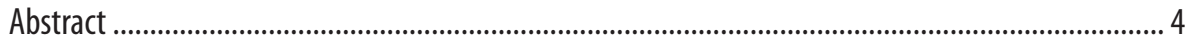

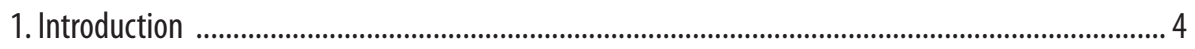

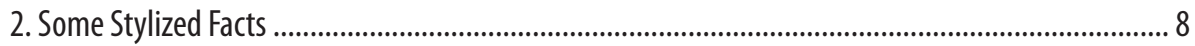

2.1 Wage Disparities in Egypt ........................................................................................ 8

2.2 Trade Liberalization and Facilitation in Egypt ................................................................. 14

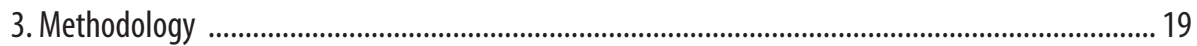

3.1 A One-Step Analysis: the Human Capital Model .................................................................. 19

3.2 A Two-Step Analysis: The Wage Premia ......................................................................... 20

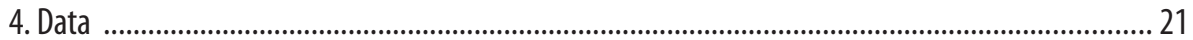

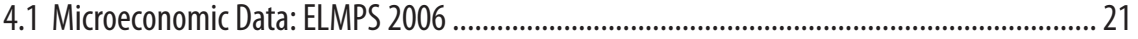

4.2 Macroeconomic Data: Trade Policy Variables ......................................................................2

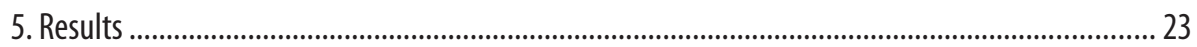

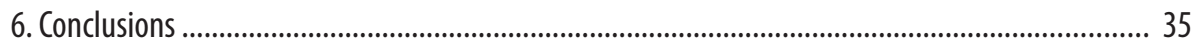

Acknowledgment ................................................................................................................. 37

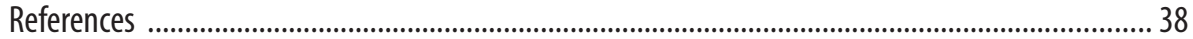




\section{Abstract}

This paper proposes an empirical investigation of the effect of different trade barriers on wages in Egypt. The effect of trade barriers on wage disparity has been widely discussed at both empirical and public policy levels. This debate mainly dealt with traditional tariff barriers. Less attention has been attributed to other barriers such as non-tariff measures and red tape costs. However, these barriers, and in particular red tape costs, are more impeding than tariffs in developing countries. Thus, using a microeconomic dataset, I try to assess to what extent different trade barriers affected wage disparity and employment in Egypt. This disparity is studied in three dimensions: on gender (males vs. females), qualification (blue vs. white collar workers), and regional (urban vs. rural workers). My main findings show that both non-tariff measures and red tape barriers have a higher impact than traditional tariffs on wage disparity. Women, urban workers, and blue collar workers are more affected by such barriers. Finally, when the effects of observable worker characteristics are filtered out, it turns out that wage premia are negatively affected by all trade barriers.

\section{JEL classification: Jor, Ji6, Fi5}

Keywords: Trade Liberalization, Trade Facilitation, Inequality, Wages, Gender.

\section{Introduction}

The effect of trade barriers on wage disparity has been widely discussed at both empirical and public policy levels. This debate mainly dealt with traditional tariff barriers. Less attention has been attributed to other barriers such as non-tariff measures and red tape costs. However, these barriers, and in particular red tape costs, are more impeding than tariffs in developing countries. The United Nations Commission on Trade and Development (UNCTAD, 200I) showed that customs procedures and transactions in developing countries involve between 20 to 30 parties, 27 to 30 stages through many intermediaries, 40 documents, 200 information elements of which 30 have to be repeated at least 30 times. Obviously, those figures show the magnitude and the cost of administrative barriers. The 
removal of such barriers is likely to have a significant impact on imports, exports, production, employment, and hence wages. This is why trade facilitation seems to be an important process in developing countries. This paper assesses the effect of administrative barriers along with tariffs and non-tariff measures on wage inequality. Such inequality will be assessed in three dimensions: gender (males vs. females), qualification (blue vs. white collar workers) and regional (urban vs. rural workers).

Likewise tariffs, administrative barriers induce distortions on the market, removing them should affect the allocation of resources and/ or terms of trade and increase the efficiency of the economy. Two main frameworks could be evoked. The Heckscher-Ohlin-Samuelson (I 933 and I94I) model was one of the first attempts to determine the effect of trade on inequality. According to the Stolper-Samuelson effect, an increase in the relative price of a good (where the country has a comparative advantage) will lead to a more than proportional increase in the real returns of the factor which is intensively used in the production of that good, and conversely, to a fall in the real returns of the other factor. Such effects are valid when factors are assumed to be mobile between different sectors. Yet, inter-sectoral mobility of the factors of production is relatively low in the short run. This is why the sector specific model (Viner, 193I) assumes that one factor of production is specific to a particular industry. A movement towards free trade increases the price of the exportable goods and reduces that of importable ones. Hence, the return of the factors used in the exporting sectors will increase while factors used in the importing sectors will witness a decline of their revenues.

Besides these effects of trade barriers, a couple of remarks are worth mentioning with respect to administrative barriers or trade facilitation. ${ }^{\mathrm{I}}$ First, since these barriers hinder both exports and imports, removing red tape costs increases the terms of trade and welfare at the national level. Consequently, this will eliminate the anti-export bias as the cost of exporting should be lower. This is why, per se, workers in all sectors should benefit from such a process, which is not the case in trade liberalization. Yet, taking into account the sectoral second-round effects, some households may witness higher or lower gains (or eventually losses) according to the comparative advantage of the country. Second, trade facilitation encompasses investment in public goods, such as transport and communications infrastructure that improves the efficiency of the trading environment and thus all industries should benefit. A better infrastructure greatly enhances households' welfare, even if they are working in a declining

1 The definition of such a process splits trade facilitation aspects into four major parts: simplification of commercial procedures; harmonization of trade rules; transparent information and procedures and the recourse to new technologies allowing trade promotion (Zaki, 2008). 
sector. Considering these two points, the impact of trade facilitation is likely to be higher than that of trade liberalization. Moreover, while trade facilitation may amplify the positive effects of trade liberalization, it may also attenuate its negative effects thanks to the effects mentioned above.

The empirical literature on trade and wage inequality is quite rich but has never considered red tape barriers. ${ }^{2}$ This literature can be classified in four main groups. The first one assesses the effect of trade barriers on wage inequality and wage premia in general. Some seminal works could be cited like Gaston and Trefler (1994) who found, for the USA, a statistically significant negative effect of tariffs on relative wages and wage premia. Goh and Javorcik (2005) showed that in Poland, workers in sectors with the largest tariff declines experienced the highest increase in wages. In India, these workers suffered the highest relative decrease in wage premia (Dutta, 2007). Said and El Azzawi (2009) examined those issues in Egypt and found that export promotion had the most important effect on wage premia. That is why trade barriers may have a positive or negative effect on wages. The reason behind such different results depend upon the protection and the trade structure. Since barriers represent a distortion on the market, they are associated with an inefficiency and a lower productivity and hence lower wages. By contrast, as they protect workers from foreign competition, they result in higher wages.

The second group determined the relationship between trade policies and skill premium. Bontout and Jean (1998) showed, using a computable general equilibrium model, that sector-biased technical change and North-North trade can significantly increase skilled labor's relative wages. Moreover, Feenstra and Hanson (200I) developed a theoretical model showing that trade in inputs has the same impact on labor demand as does skill-biased technical change since both of these will shift demand away from low-skilled activities and raise the relative demand and wages of the better-skilled. Meschi et al. (2009) found in Turkey that firms belonging to the sectors that increased their imported inputs from more developed countries witnessed a higher increase in their share of skilled workers. While Blom et al. (2004) concluded that trade liberalization in Brazil did not significantly contribute to increased wage inequality between the skilled and unskilled workers through changes in industry wage premia, Araújo et al. (2009) showed that Brazilian manufacturing firms raised their imports of capital goods involving a skill-biased technological change in this sector. Finally, Attanasio et al. (2004) proved that, in Colombia, the increase in the skill premium has been driven by skilled-biased technological change thanks to drastic liberalization.

2 For an extensive literature review, see Goldberg and Pavnick (2007b) 
The third group encompasses studies that assessed the effect of trade barriers on regional inequality. Puga (1999), Puga and Venables (1999), and Sutton (2002) examined the determinants of firms agglomeration and their effects on wage inequality. Paluzie (200I) found that regional inequality rises as international trade in manufacturing increases. Nicita (2004) found that, in Mexico, trade liberalization has contributed to an increase in inequality between the south and the north of the country, urban and rural areas, and skilled and unskilled labor. While Goldberg and Pavnick (2007a) failed to find evidence between the trade reforms and the changes in urban poverty in Colombia, Topalova (2005) showed that the decline in tariffs as a result of the sharp trade liberalization appears to have led to a relative increase in the poverty rate and poverty gap in districts of which exposure to liberalization was more intense. ${ }^{3}$

Finally, the fourth group includes studies that focused on the link between trade and gender inequality. Among the very first studies, Becker (1971) showed that, theoretically, free trade implies a more competitive environment and, consequently, a less discriminating economy. Artecona and Cunningham (2002) found that the gender wage gap fell in the industries that were forced to become competitive due to trade liberalization. Similarly, Klein et al. (2010) proved that an increase in exports increases wage inequality along the dimension of skill but in the mean time it reduces the wage inequality associated with gender and nationality differences. In Mexico, Aguayo-Tellez et al. (2010) found that the relative wages of women remained stable while employment increased, leading to an increase in their wage bill share.

In the case of Egypt, existing work has pointed out to persistent inequalities at these different levels. At the regionallevel, Said (2007) showed that living outside greater Cairo is associated with a wage disadvantage for all sector and gender groups. Concerning gender inequality, Said (2007) also found that, after correcting for productivity differences, the gap in favor of females is only $3 \%$ in government sectors and the one in favor of males is $21 \%$ in the private sector. El Hamidi (2008) argued that, during trade liberalization periods, the tradables sector experienced higher wage gaps between males and females than the non-tradables sector. Yet, the effect of trade policies and the skill premium has never been studied in the Egyptian case.

In all of these studies, red tape barriers were never considered despite their highly negative impact. Therefore, this paper seeks to take a first

3 The difference between the two papers lies in the liberalization of the agricultural sector that may have a significant effect on poverty in the short and medium run. While India experienced significant tariff reductions in the agricultural sector, agricultural trade liberalization in Colombia was limited. This is why Colombian poor in rural areas were not affected by the liberalization waves. 
step toward assessing the effect of different trade barriers on wages in Egypt. Being more affected by trade policies, I select wage inequality (real hourly wage) rather than income inequality in order to assess the effect of different barriers. ${ }^{4}$ This paper has two contributions. First, traditional tariffs, non-tariff measures and red tape barriers are simultaneously taken into account. Second, disparity is studied in three dimensions: gender (males vs. females), qualification (skilled vs. unskilled), and regional (urban vs. rural workers). This is why this paper combines both microeconomic (Egyptian Labor Market Panel Survey, 2006) and macroeconomic (for different types of barriers) datasets. The ad valorem equivalents (AVEs) of red tape costs are estimated in a companion paper (Zaki, 2009).

The main findings show that non-tariff measures as well as red tape barriers have a higher impact than classic tariffs on wage disparity. Females, urban workers, and blue collar workers are more affected by such barriers. Finally, when the effects of observable worker characteristics are filtered out, it turns out that wage premia are negatively affected by all trade barriers.

The paper is organized as follows: Section 2 presents some stylized facts regarding wage disparities. It also gives the main liberalization and facilitation changes that took place in the Egyptian economy. Section 3 displays the methodology. Section 4 is devoted to the data presentation. Section 5 presents the main results and Section 6 concludes.

\section{Some Stylized Facts}

\subsection{Wage Disparities in Egypt}

Wage disparities remain a serious issue in Egypt. Such disparity is observed at many levels: gender, qualification, and geography. According to the World Bank (2005), the Gini index in Egypt is 32.I. More precisely, the income share held by the lowest $10 \%$ of the population is $3.7 \%$ and the one held by the lowest $20 \%$ is $9 \%$. Those figures are much higher for the highest $20 \%$ and $10 \%$ (44\% and $30 \%$ respectively).

Although the situation for women has improved significantly, they still earn less than men. Yet, as mentioned by Said (2007), the female relative

4 According to Milanovic and Squire (2007), the link between policy reforms and wage inequality is likely to be stronger than the link between policy reforms and inequality in total income. The latter is affected by a number of other institutional factors such as the role of social transfers (pension spending or family benefits), demographics of the population and labor force participation. By contrast, wage inequality does not depend on such factors. Thus, the link between trade policy and wages must be stronger than that between trade policy and the distribution of total income. 
rewards witnessed larger real wage improvements in comparison to their male counterparts between 1998 and 2006 (the gap in favor of females is only $3 \%$ in government sectors and the one in favor of males is $21 \%$ in the private sector). This is thanks to the fact that women are concentrated in the government sector that guarantees stability, suitable revenues, flexible maternity leave, and not requiring much time. In this sector, real wages increased by $40 \%$ as opposed to only $17 \%$ in the private sector. In addition, by observing the most important sectors intensive in female labor, textiles and garments, retail and trade; and education and health rank first. In particular, textiles and garments are witnessing a significant openness at both national and international levels. At the national level, import prohibitions were lifted on most textile and clothing products in 2004, through the ministerial decree I6I/2004. Meanwhile, the imports of some products are subject to specific administrative formalities, inducing additional red tape costs. Even though quotas seem to have no effect on Egyptian trade, the trade facilitation issues still hinder some imports as well as exports. At the international level, the dismantlement of the Multi-Fiber Agreement (MFA) in January 2005 has put an end to all quota barriers impeding the textiles and garments trade. Consequently, Egypt should face a fierce competition coming from other countries, especially in Asia, whose exports are much more competitive. This, in turn, could have a negative effect on Egyptian exports, employment, wages, and hence inequality.

As shown in Table $\mathrm{I}$, males are distributed in different manufacturing sectors while females are mainly working in textile, garments, and food. Therefore, garments liberalization means more trade, higher expansion, and greater wages for females who are working in these sectors. Table 2 shows that almost all the manufacturing sectors (except garments) are more intensive in males than females. Females represent only some $13 \%$ of the labor force in the manufacturing sector in Egypt.

Table 1: Distribution of Labor in Manufacturing: By Gender, Qualification and Regions, 20

\begin{tabular}{|l|c|c|c|c|c|c|c|}
\hline & Males & Females & Urban & Rural & Unskilled & Skilled & Total \\
\hline Food and Beverage & $19.1 \%$ & $18.0 \%$ & $16.6 \%$ & $23.6 \%$ & $19.0 \%$ & $18.9 \%$ & $19.0 \%$ \\
\hline Tobacco & $0.7 \%$ & $0.7 \%$ & $0.9 \%$ & $0.3 \%$ & $0.5 \%$ & $1.3 \%$ & $0.7 \%$ \\
\hline Textiles & $9.8 \%$ & $14.0 \%$ & $10.6 \%$ & $10.0 \%$ & $10.4 \%$ & $10.3 \%$ & $10.4 \%$ \\
\hline Garment & $6.5 \%$ & $39.3 \%$ & $12.6 \%$ & $7.0 \%$ & $12.5 \%$ & $5.6 \%$ & $10.7 \%$ \\
\hline Leather Goods & $2.0 \%$ & $4.0 \%$ & $3.0 \%$ & $1.0 \%$ & $3.0 \%$ & $0.3 \%$ & $2.3 \%$ \\
\hline $\begin{array}{l}\text { Wood Product } \\
\text { (except furniture) }\end{array}$ & $3.0 \%$ & $0.7 \%$ & $1.9 \%$ & $4.3 \%$ & $3.7 \%$ & $0.0 \%$ & $2.7 \%$ \\
\hline
\end{tabular}




\begin{tabular}{|l|c|c|c|c|c|c|c|}
\hline Paper & $1.8 \%$ & $1.3 \%$ & $1.7 \%$ & $1.8 \%$ & $1.9 \%$ & $1.0 \%$ & $1.7 \%$ \\
\hline $\begin{array}{l}\text { Publishing and } \\
\text { Printing }\end{array}$ & $3.4 \%$ & $2.0 \%$ & $3.7 \%$ & $2.3 \%$ & $2.4 \%$ & $5.6 \%$ & $3.2 \%$ \\
\hline $\begin{array}{l}\text { Coke and Petroleum } \\
\text { Products }\end{array}$ & $4.6 \%$ & $4.0 \%$ & $5.5 \%$ & $2.5 \%$ & $2.4 \%$ & $10.6 \%$ & $4.5 \%$ \\
\hline Chemical Product & $7.3 \%$ & $8.7 \%$ & $9.7 \%$ & $3.3 \%$ & $6.1 \%$ & $11.6 \%$ & $7.5 \%$ \\
\hline Rubber Product & $1.2 \%$ & $0.0 \%$ & $0.8 \%$ & $1.5 \%$ & $1.0 \%$ & $1.0 \%$ & $1.0 \%$ \\
\hline $\begin{array}{l}\text { Non-metallic } \\
\text { Mineral }\end{array}$ & $9.6 \%$ & $1.3 \%$ & $6.7 \%$ & $12.0 \%$ & $9.3 \%$ & $6.3 \%$ & $8.5 \%$ \\
\hline Basic Metal & $2.6 \%$ & $0.7 \%$ & $2.4 \%$ & $2.3 \%$ & $2.1 \%$ & $3.3 \%$ & $2.4 \%$ \\
\hline Metallic Product & $7.5 \%$ & $0.0 \%$ & $7.5 \%$ & $4.8 \%$ & $7.2 \%$ & $4.7 \%$ & $6.5 \%$ \\
\hline $\begin{array}{l}\text { Machinery and } \\
\text { Equipment }\end{array}$ & $5.1 \%$ & $1.3 \%$ & $5.5 \%$ & $2.8 \%$ & $2.6 \%$ & $10.3 \%$ & $4.6 \%$ \\
\hline $\begin{array}{l}\text { Electrical } \\
\text { Equipment }\end{array}$ & $0.5 \%$ & $1.3 \%$ & $0.5 \%$ & $0.8 \%$ & $0.3 \%$ & $1.3 \%$ & $0.6 \%$ \\
\hline $\begin{array}{l}\text { Radio, TV, and Com. } \\
\text { Equip. }\end{array}$ & $0.9 \%$ & $0.7 \%$ & $1.0 \%$ & $0.5 \%$ & $0.1 \%$ & $3.0 \%$ & $0.9 \%$ \\
\hline Medical Equipment & $0.3 \%$ & $1.3 \%$ & $0.6 \%$ & $0.0 \%$ & $0.1 \%$ & $1.3 \%$ & $0.4 \%$ \\
\hline $\begin{array}{l}\text { Other Transport } \\
\text { Equipment }\end{array}$ & $0.6 \%$ & $0.7 \%$ & $0.8 \%$ & $0.3 \%$ & $0.2 \%$ & $1.7 \%$ & $0.6 \%$ \\
\hline Furniture & $13.5 \%$ & $0.0 \%$ & $8.0 \%$ & $19.3 \%$ & $15.3 \%$ & $1.7 \%$ & $11.8 \%$ \\
\hline Total & $100.0 \%$ & $100.0 \%$ & $100.0 \%$ & $100.0 \%$ & $100.0 \%$ & $100.0 \%$ & $100.0 \%$ \\
\hline
\end{tabular}

Source: Constructed by the author from ELMPS, 2006.

Table 2: Distribution of Labor in Manufacturing: By Gender, Qualification and Regions, 2006

\begin{tabular}{|l|c|c|c|c|c|c|c|}
\hline & Males & Females & Urban & Rural & Unskilled & Skilled & Total \\
\hline $\begin{array}{l}\text { Food and } \\
\text { Beverage }\end{array}$ & $87.9 \%$ & $12.1 \%$ & $57.9 \%$ & $42.2 \%$ & $74.4 \%$ & $25.6 \%$ & $100.0 \%$ \\
\hline Tobacco & $87.5 \%$ & $12.5 \%$ & $87.5 \%$ & $12.5 \%$ & $50.0 \%$ & $50.0 \%$ & $100.0 \%$ \\
\hline Textiles & $82.8 \%$ & $17.2 \%$ & $67.2 \%$ & $32.8 \%$ & $74.6 \%$ & $25.4 \%$ & $100.0 \%$ \\
\hline Garment & $53.2 \%$ & $46.8 \%$ & $77.8 \%$ & $22.2 \%$ & $86.5 \%$ & $13.5 \%$ & $100.0 \%$ \\
\hline Leather Goods & $77.8 \%$ & $22.2 \%$ & $85.2 \%$ & $14.8 \%$ & $96.3 \%$ & $3.7 \%$ & $100.0 \%$ \\
\hline $\begin{array}{l}\text { Wood Product } \\
\text { (expt Furniture) }\end{array}$ & $96.9 \%$ & $3.1 \%$ & $46.9 \%$ & $53.1 \%$ & $100.0 \%$ & $0.0 \%$ & $100.0 \%$ \\
\hline Paper & $90.0 \%$ & $10.0 \%$ & $65.0 \%$ & $35.0 \%$ & $85.0 \%$ & $15.0 \%$ & $100.0 \%$ \\
\hline $\begin{array}{l}\text { Publishing and } \\
\text { Printing }\end{array}$ & $92.1 \%$ & $7.9 \%$ & $76.3 \%$ & $23.7 \%$ & $55.3 \%$ & $44.7 \%$ & $100.0 \%$ \\
\hline $\begin{array}{l}\text { Coke and Petro. } \\
\text { Products }\end{array}$ & $88.7 \%$ & $11.3 \%$ & $81.1 \%$ & $18.9 \%$ & $39.6 \%$ & $60.4 \%$ & $100.0 \%$ \\
\hline
\end{tabular}




\begin{tabular}{|l|c|c|c|c|c|c|c|}
\hline $\begin{array}{l}\text { Chemical } \\
\text { Product }\end{array}$ & $85.2 \%$ & $14.8 \%$ & $85.2 \%$ & $14.8 \%$ & $60.2 \%$ & $39.8 \%$ & $100.0 \%$ \\
\hline Rubber Product & $100.0 \%$ & $0.0 \%$ & $50.0 \%$ & $50.0 \%$ & $75.0 \%$ & $25.0 \%$ & $100.0 \%$ \\
\hline $\begin{array}{l}\text { Non-metallic } \\
\text { Mineral }\end{array}$ & $98.0 \%$ & $2.0 \%$ & $52.0 \%$ & $48.0 \%$ & $81.0 \%$ & $19.0 \%$ & $100.0 \%$ \\
\hline Basic Metal & $96.4 \%$ & $3.6 \%$ & $67.9 \%$ & $32.1 \%$ & $64.3 \%$ & $35.7 \%$ & $100.0 \%$ \\
\hline Metallic Product & $100.0 \%$ & $0.0 \%$ & $75.3 \%$ & $24.7 \%$ & $81.8 \%$ & $18.2 \%$ & $100.0 \%$ \\
\hline $\begin{array}{l}\text { Machinery and } \\
\text { Equipment }\end{array}$ & $96.3 \%$ & $3.7 \%$ & $79.6 \%$ & $20.4 \%$ & $42.6 \%$ & $57.4 \%$ & $100.0 \%$ \\
\hline $\begin{array}{l}\text { Electrical } \\
\text { Equipment }\end{array}$ & $71.4 \%$ & $28.6 \%$ & $57.1 \%$ & $42.9 \%$ & $42.9 \%$ & $57.1 \%$ & $100.0 \%$ \\
\hline $\begin{array}{l}\text { Radio, TV, and } \\
\text { Com. Equip. }\end{array}$ & $90.0 \%$ & $10.0 \%$ & $80.0 \%$ & $20.0 \%$ & $10.0 \%$ & $90.0 \%$ & $100.0 \%$ \\
\hline $\begin{array}{l}\text { Medical } \\
\text { Equipment }\end{array}$ & $60.0 \%$ & $40.0 \%$ & $100.0 \%$ & $0.0 \%$ & $20.0 \%$ & $80.0 \%$ & $100.0 \%$ \\
\hline $\begin{array}{l}\text { Other Transport } \\
\text { Equipment }\end{array}$ & $85.7 \%$ & $14.3 \%$ & $85.7 \%$ & $14.3 \%$ & $28.6 \%$ & $71.4 \%$ & $100.0 \%$ \\
\hline Furniture & $100.0 \%$ & $0.0 \%$ & $44.6 \%$ & $55.4 \%$ & $96.4 \%$ & $3.6 \%$ & $100.0 \%$ \\
\hline Total & $87.2 \%$ & $12.8 \%$ & $66.1 \%$ & $33.9 \%$ & $74.4 \%$ & $25.6 \%$ & $100.0 \%$ \\
\hline
\end{tabular}

Source: Constructed by the author from ELMPS, 2006.

Regarding geographical inequality, urban areas and especially Greater Cairo represent a center attracting firms and educated persons to the detriment of other governorates. ${ }^{5}$ Thus, workers in the latter will earn less than in the former. Said (2007) showed that living outside greater Cairo is associated with a wage disadvantage for all sector and gender groups. Many efforts have been deployed to reverse these trends in 1990 and succeeded to reduce such disadvantage in 2006 , but according to her findings, urban and rural lower Egypt areas still suffer from the greatest disadvantage. Table I shows that the distribution of urban and rural workers is the same in different sectors except food and furniture where rural persons are mainly working. Yet, Table 2 points out the fact that urban employment represents $66 \%$ of the labor force in the manufacturing sector. Almost all sectors are more intensive in urban workers than rural ones. This shows to what extent the geographical location may affect employment and wages.

Finally, I distinguish skilled and unskilled workers according to their occupation. While the former are white collar workers (technical and scientific; managers; clerical; sales and services), the latter are blue collar workers (agriculture and production workers). ${ }^{6}$ Having a look on

5 Egypt is divided into 29 governorates.

6 For the sake of robustness check, skilled and unskilled workers have been distinguished on the basis of their education levels. It turns out that figures do not change. 
qualification in different sectors, it is quite clear that garments, textiles, food and beverages, and furniture are intensive in unskilled labor while machinery and equipment are more intensive in skilled ones. Unskilled employment represents $75 \%$ of the labor force in the manufacturing sector.

Combining these three criterion together (i.e. gender, qualification, and region), Table 3 displays the number of workers by segment and by sector. The majority of unskilled females are working in garments $(50.5 \%$ and $43 \%$ in urban and rural areas respectively). Concerning males, skilled ones in urban areas work mainly in machinery, chemicals, and food (I2.2\%, $\mathrm{I} 3 . \mathrm{I} \%$, and $\mathrm{I} 8.8 \%$ respectively).

Table 3: Employment by Sector and by Segment, 2006

\begin{tabular}{|c|c|c|c|c|c|c|c|c|c|}
\hline & \multicolumn{4}{|c|}{ Males } & \multicolumn{4}{|c|}{ Females } & \multirow[b]{3}{*}{ Tota } \\
\hline & \multicolumn{2}{|c|}{ Skilled } & \multicolumn{2}{|c|}{ Unskilled } & \multicolumn{2}{|c|}{ Skilled } & \multicolumn{2}{|c|}{ Unskilled } & \\
\hline & Urban & Rural & Urban & Rural & \begin{tabular}{|l|} 
Urban \\
\end{tabular} & Rural & Urban & Rural & \\
\hline Food and Beverage & 40 & 11 & 76 & 69 & 5 & 1 & 8 & 13 & 223 \\
\hline Tobacco & 3 & 0 & 3 & 1 & 1 & 0 & 0 & 0 & 8 \\
\hline Textiles & 16 & 8 & 49 & 28 & 7 & 0 & 10 & 4 & 122 \\
\hline Garment & 8 & 0 & 47 & 12 & 8 & 1 & 35 & 15 & 126 \\
\hline Leather & 1 & 0 & 17 & 3 & 0 & 0 & 5 & 1 & 27 \\
\hline $\begin{array}{l}\text { Wood Prod. (except } \\
\text { Furniture) }\end{array}$ & 0 & 0 & 15 & 16 & 0 & 0 & 0 & 1 & 32 \\
\hline Paper & 3 & 0 & 8 & 7 & 0 & 0 & 2 & 0 & 20 \\
\hline $\begin{array}{l}\text { Publishing and } \\
\text { Printing }\end{array}$ & 10 & 4 & 16 & 5 & 3 & 0 & 0 & 0 & 38 \\
\hline Coke and Petro. Prod. & 23 & 3 & 15 & 6 & 5 & 1 & 0 & 0 & 53 \\
\hline Chemical Prod. & 28 & 1 & 35 & 11 & 6 & 0 & 6 & 1 & 88 \\
\hline Rubber Prod. & 2 & 1 & 4 & 5 & 0 & 0 & 0 & 0 & 12 \\
\hline Non-metallic Mineral & 17 & 0 & 33 & 48 & 2 & 0 & 0 & 0 & 100 \\
\hline Basic Metal & 7 & 2 & 11 & 7 & 1 & 0 & 0 & 0 & 28 \\
\hline Metallic Prod. & 12 & 2 & 46 & 17 & 0 & 0 & 0 & 0 & 77 \\
\hline Machinery and & 26 & 4 & 15 & 7 & 1 & 0 & 1 & 0 & 54 \\
\hline $\begin{array}{l}\text { Electrical Equip. } \\
\text { (Other) }\end{array}$ & 1 & 2 & 1 & 1 & 1 & 0 & 1 & 0 & 7 \\
\hline $\begin{array}{l}\text { Radio, TV, and Com. } \\
\text { Equip. }\end{array}$ & 7 & 1 & 0 & 1 & 1 & 0 & 0 & 0 & 10 \\
\hline Medical IEquip. & 2 & 0 & 1 & 0 & 2 & 0 & 0 & 0 & 5 \\
\hline $\begin{array}{l}\text { Other Transport } \\
\text { Equip. }\end{array}$ & 3 & 1 & 2 & 0 & 1 & 0 & 0 & 0 & 7 \\
\hline Furniture & 4 & 1 & 58 & 76 & 0 & 0 & 0 & 0 & 139 \\
\hline Total & 213 & 41 & 452 & 320 & 44 & 3 & 68 & 35 & 1176 \\
\hline
\end{tabular}

Source: Constructed by the author from ELMPS, 2006. 
In summary, all sectors are mainly intensive in urban and blue collar workers. Therefore, trade facilitation and liberalization will primarily benefit these workers as it is shown in Table 4 .

Table 4: Employment by Sector and by Segment, 2006

\begin{tabular}{|l|c|c|c|c|c|c|c|c|c|}
\hline & \multicolumn{5}{|c}{ Males } & \multicolumn{5}{c|}{ Females } & RCA \\
\hline & White Collar & \multicolumn{2}{|c|}{ Blue Collar } & White Collar & Blue Collar & \\
\hline & Urban & Rural & Urban & Rural & Urban & Rural & Urban & Rural & \\
\hline $\begin{array}{l}\text { Coke and Petro. } \\
\text { Prod. }\end{array}$ & $43.4 \%$ & $5.7 \%$ & $28.3 \%$ & $11.3 \%$ & $9.4 \%$ & $1.9 \%$ & $0.0 \%$ & $0.0 \%$ & 25.44 \\
\hline $\begin{array}{l}\text { Non-metallic } \\
\text { Mineral }\end{array}$ & $17.0 \%$ & $0.0 \%$ & $33.0 \%$ & $48.0 \%$ & $2.0 \%$ & $0.0 \%$ & $0.0 \%$ & $0.0 \%$ & 3.97 \\
\hline Basic Metal & $25.0 \%$ & $7.1 \%$ & $39.3 \%$ & $25.0 \%$ & $3.6 \%$ & $0.0 \%$ & $0.0 \%$ & $0.0 \%$ & 3.47 \\
\hline Garment & $6.3 \%$ & $0.0 \%$ & $37.3 \%$ & $9.5 \%$ & $6.3 \%$ & $0.8 \%$ & $27.8 \%$ & $11.9 \%$ & 3.09 \\
\hline Textiles & $13.1 \%$ & $6.6 \%$ & $40.2 \%$ & $23.0 \%$ & $5.7 \%$ & $0.0 \%$ & $8.2 \%$ & $3.3 \%$ & 2.86 \\
\hline Leather Goods & $3.7 \%$ & $0.0 \%$ & $63.0 \%$ & $11.1 \%$ & $0.0 \%$ & $0.0 \%$ & $18.5 \%$ & $3.7 \%$ & 1.01 \\
\hline Food and Beverage & $17.9 \%$ & $4.9 \%$ & $34.1 \%$ & $30.9 \%$ & $2.2 \%$ & $0.4 \%$ & $3.6 \%$ & $5.8 \%$ & 0.92 \\
\hline Chemical Product & $31.8 \%$ & $1.1 \%$ & $39.8 \%$ & $12.5 \%$ & $6.8 \%$ & $0.0 \%$ & $6.8 \%$ & $1.1 \%$ & 0.69 \\
\hline Furniture & $2.9 \%$ & $0.7 \%$ & $41.7 \%$ & $54.7 \%$ & $0.0 \%$ & $0.0 \%$ & $0.0 \%$ & $0.0 \%$ & 0.65 \\
\hline Rubber Product & $16.7 \%$ & $8.3 \%$ & $33.3 \%$ & $41.7 \%$ & $0.0 \%$ & $0.0 \%$ & $0.0 \%$ & $0.0 \%$ & 0.57 \\
\hline Tobacco & $37.5 \%$ & $0.0 \%$ & $37.5 \%$ & $12.5 \%$ & $12.5 \%$ & $0.0 \%$ & $0.0 \%$ & $0.0 \%$ & 0.53 \\
\hline Metallic Prod. & $15.6 \%$ & $2.6 \%$ & $59.7 \%$ & $22.1 \%$ & $0.0 \%$ & $0.0 \%$ & $0.0 \%$ & $0.0 \%$ & 0.52 \\
\hline $\begin{array}{l}\text { Publishing and } \\
\text { Printing }\end{array}$ & $26.3 \%$ & $10.5 \%$ & $42.1 \%$ & $13.2 \%$ & $7.9 \%$ & $0.0 \%$ & $0.0 \%$ & $0.0 \%$ & 0.49 \\
\hline Paper & $15.0 \%$ & $0.0 \%$ & $40.0 \%$ & $35.0 \%$ & $0.0 \%$ & $0.0 \%$ & $10.0 \%$ & $0.0 \%$ & 0.47 \\
\hline Wood Product & $0.0 \%$ & $0.0 \%$ & $46.9 \%$ & $50.0 \%$ & $0.0 \%$ & $0.0 \%$ & $0.0 \%$ & $3.1 \%$ & 0.26 \\
\hline $\begin{array}{l}\text { Radio, TV, and Com. } \\
\text { Equip. }\end{array}$ & $70.0 \%$ & $10.0 \%$ & $0.0 \%$ & $10.0 \%$ & $10.0 \%$ & $0.0 \%$ & $0.0 \%$ & $0.0 \%$ & 0.24 \\
\hline Machine and Equip. & $48.1 \%$ & $7.4 \%$ & $27.8 \%$ & $13.0 \%$ & $1.9 \%$ & $0.0 \%$ & $1.9 \%$ & $0.0 \%$ & 0.14 \\
\hline Electrical Equip. & $14.3 \%$ & $28.6 \%$ & $14.3 \%$ & $14.3 \%$ & $14.3 \%$ & $0.0 \%$ & $14.3 \%$ & $0.0 \%$ & 0.13 \\
\hline Medical Equip. & $40.0 \%$ & $0.0 \%$ & $20.0 \%$ & $0.0 \%$ & $40.0 \%$ & $0.0 \%$ & $0.0 \%$ & $0.0 \%$ & 0.13 \\
\hline Other Transp. Equip. & $42.9 \%$ & $14.3 \%$ & $28.6 \%$ & $0.0 \%$ & $14.3 \%$ & $0.0 \%$ & $0.0 \%$ & $0.0 \%$ & 0.10 \\
\hline
\end{tabular}

Source: Constructed by the author from ELMPS, 2006.

After observing the labor market characteristics, Table 5 shows the wages landscape for each segment in Egypt. Since the median is a more robust measure of central tendency than mean, I will stick to the median of wages for each segment. The median of wages for women is always lower than their male counterparts. The highest median wage is the one of urban skilled males followed by rural skilled males, urban skilled females, 
and urban unskilled males. On the other extreme, the lowest median wage is the one of rural skilled females, urban and rural unskilled females, and rural unskilled males. Such an analysis shows that being a female, unskilled, or a rural workers reduces one's wage. Interestingly, the effect of being a female reduces wages more since urban unskilled males are more paid than urban skilled females.

Table 5: Wages by Segment, 2006

\begin{tabular}{|c|c|c|c|c|c|c|c|c|c|}
\hline \multicolumn{2}{|l|}{} & \multicolumn{2}{|c|}{ Workers } & \multicolumn{5}{c|}{ Wages } \\
\hline \multicolumn{2}{|c|}{} & & Number & Share & Mean & Median & $\begin{array}{c}\text { Std } \\
\text { Dev }\end{array}$ & Min & Max \\
\hline Males & Skilled & Urban & 213 & $18.11 \%$ & 5.59 & 3.12 & 10.91 & 0.80 & 137.88 \\
\hline & & Rural & 41 & $3.49 \%$ & 2.59 & 2.18 & 1.48 & 0.50 & 7.05 \\
\hline & Unskilled & Urban & 452 & $38.44 \%$ & 2.81 & 1.92 & 4.95 & 0.27 & 76.70 \\
\hline & & Rural & 320 & $27.21 \%$ & 2.15 & 1.80 & 1.73 & 0.38 & 22.25 \\
\hline Females & Skilled & Urban & 44 & $3.74 \%$ & 3.25 & 2.14 & 3.87 & 0.27 & 23.08 \\
\hline & & Rural & 3 & $0.26 \%$ & 13.64 & 0.86 & 22.16 & 0.83 & 39.23 \\
\hline & Unskilled & Urban & 68 & $5.78 \%$ & 2.98 & 0.96 & 10.72 & 0.23 & 86.67 \\
\hline & & Rural & 35 & $2.98 \%$ & 3.41 & 1.00 & 8.44 & 0.60 & 48.27 \\
\hline Total & & & 1176 & $100.00 \%$ & 3.20 & 2.00 & 6.59 & 0.23 & 137.88 \\
\hline
\end{tabular}

Source: Constructed by the author from ELMPS, 2006.

Bearing in mind these facts regarding the major characteristics of labor and wage disparity, it is worth finding to what extent trade policy affects wage disparities in Egypt. That is why I will present the main characteristics of Egyptian trade policy.

\subsection{Trade Liberalization and Facilitation in Egypt}

Since the beginning of the I990's, Egypt, witnessing both macro and microeconomic changes, has undertaken many trade liberalization policies, in particular through the Economic Reform and Structural Adjustment Program (ERSAP). 7 The latter aimed at increasing the private sector participation, opening the economy, privatizing some state owned firms and hence beginning the transition to a market economy. That is why Egypt's trade has increased significantly between 1990 and 2006 thanks to an important decline in tariffs. However, non-tariff measures as well as red tape barriers are still impeding trade as it will be shown below.

7 For more details about the ERSAP effect, see Korayem (1997). 
Over two decades, Egypt has significantly liberalized its external trade. The maximum tariff rate has decreased from IIo\% at the end of the I980's to reach $40 \%$ in the end of 1990's. In 2004, the government of Egypt launched the second wave of liberalization. Its objectives were twofold: first, to reduce tariffs and rationalize the tariff structure; and second, to reduce the number of products subject to non-tariff barriers. The number of tariff bands was narrowed from 27 tariff brackets to 6 , tariff dispersion measured by standard deviation declined from I6.I in 2000 to 12.7 in 2004 and tariff lines were reduced from 8,000 to 6 ,000. Both nominal and effective protection have declined in the manufacturing sector from $2 \mathrm{I} .3 \%$ to $12.1 \%$ and from $23.3 \%$ to $14 \%$ respectively after the 2004 reform. All those measures should in turn simplify procedures, minimize tariff evasion, and remove possibilities of discretion and corruption. Figure I presents tariffs structure in manufacturing sectors. It is quite clear that tobacco, garments, and leather products have a high tariff rate while paper manufacturing, basic metal, and transport equipment are characterized by a low protection.

Figure 1: Tariff Barriers in Egypt

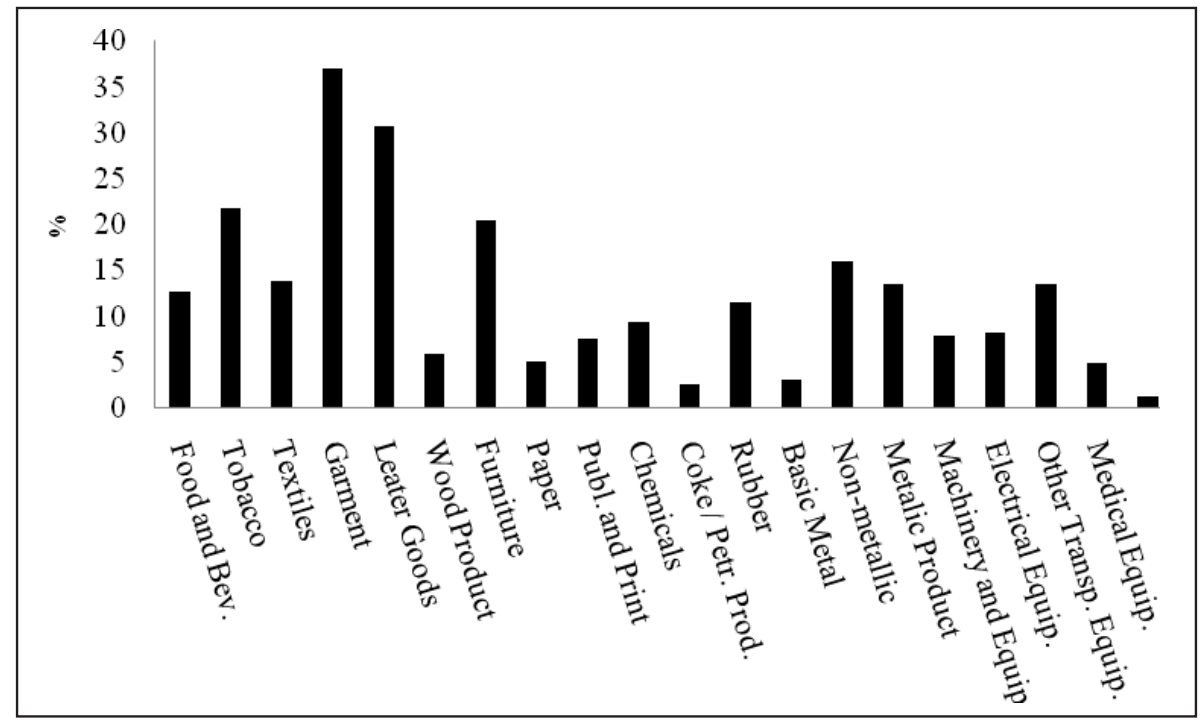

Source: Constructed by the author from the World Tariff Profile.

Note: Figures show the ad valorem applied tariffs in percentage.

Having a glance on non-tariff measures, the picture is not the same. Figure 2 displays the frequency index of non-tariff measures in Egypt coming from the "Trade and Production dataset." Food, beverages, textiles, garments, and machinery suffer more than other sectors from 
such measures since they are subject to many sanitary and phyto-sanitary measures and technical barriers to trade.

Figure 2: Non-Tariff Barriers in Egypt

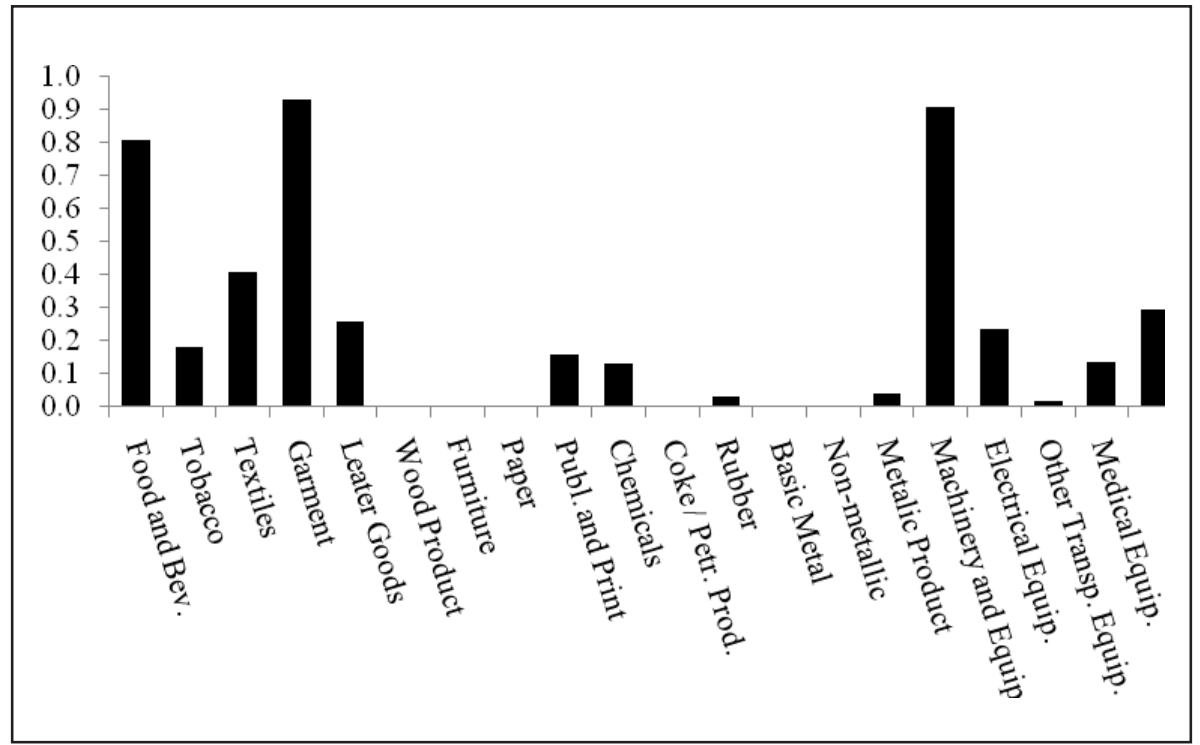

Source: Constructed by the author from the Trade and Production dataset.

Note: Figures show the frequency index of non-tariff measures (scaled from 0 to 1 . The higher the value of the index, the more frequent the non-tariff measures).

Apart from the traditional tariff and non-tariff barriers, red tape procedures for exports and imports remain high and costly in Egypt. In 2007, export procedures need 20 days costing U.S.\$ I,OI4 and import ones need 25 days adding some U.S.\$ I,049 to the value of imported goods. Yet, between 2006 and 2009 , the number of documents to be filed for exports and imports decreased from 8 to 6 documents. The same pattern is observed for time since the number of days to export has fallen from 27 to 15 and from 29 to 18 for imports. Egypt still has a long way to go to reach better rankings in the ease of doing business or best practise countries in trade facilitation aspects. That is why such administrative barriers should obviously have an impact on wages like tariff barriers or even more. To better assess the effect of such barriers, I have estimated the ad valorem equivalent (AVEs) of such barriers in Zaki (2009). Those AVEs take into account the effect of bureaucracy, internet, corruption and geographical impediments on the time to export and to import. Figures 3 and 4 display those AVEs. Perishable (food), seasonal (textiles and garments), and high value added products (medical equipment and machinery) have higher 
AVEs than tobacco, coke, or wood products that are not sensitive to the transaction time of trade.

Figure 3: Ad Valorem Equivalent of Time to Import

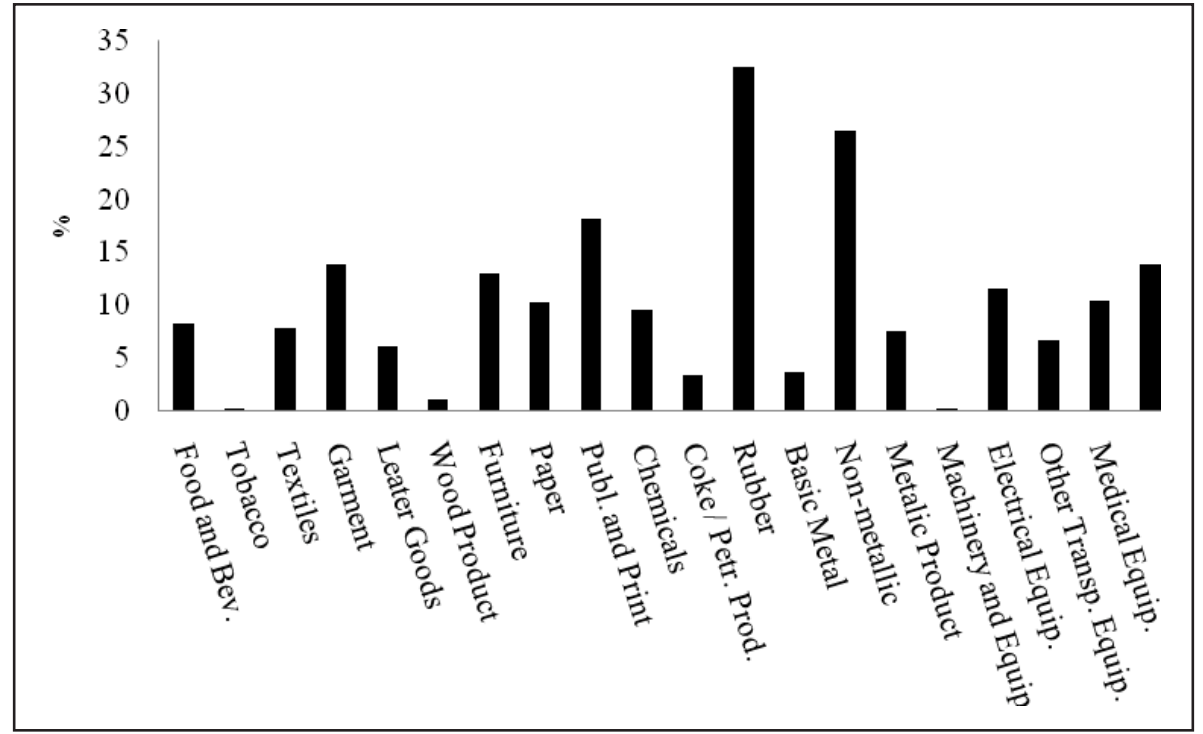

Source: Constructed by the author.

Note: Figures show the estimated ad valorem equivalent of time to import in percentage.

Figure 4: Ad Valorem Equivalent of Time to Export

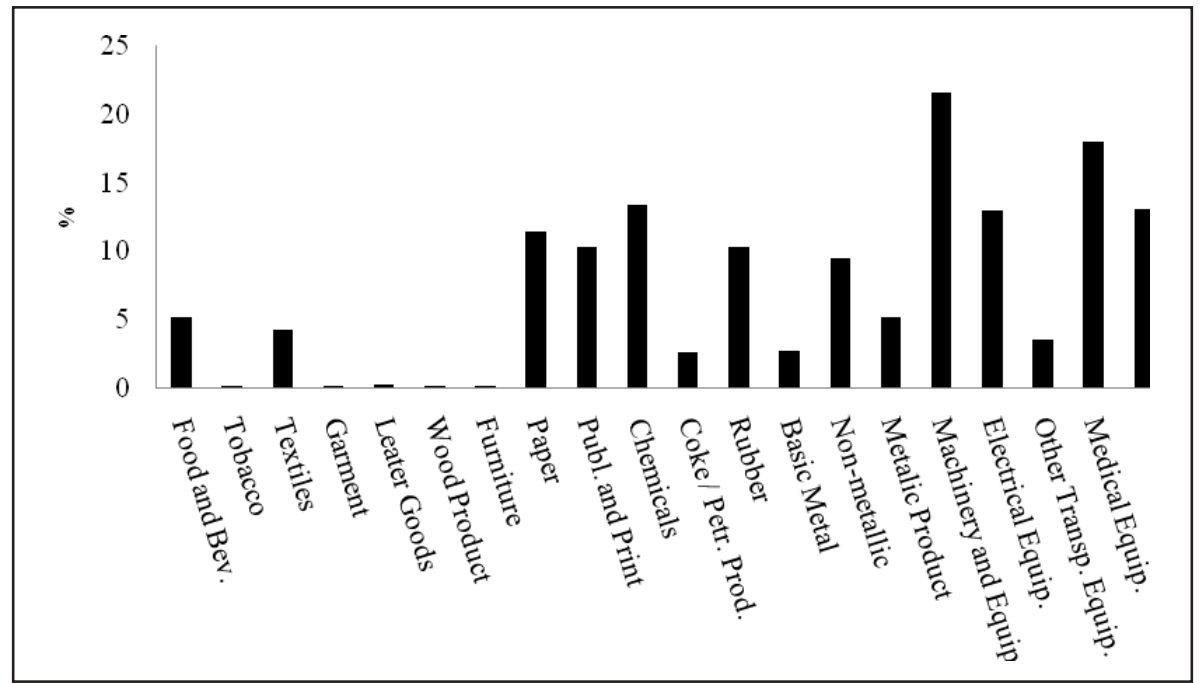

Source: Constructed by the author.

Note: Figures show the estimated ad valorem equivalent of time to export in percentage. 
To determine which workers will be affected by trade facilitation or trade liberalization, it is important to have a view of the sectors where Egypt has a comparative advantage. As it was mentioned before, according to the sector specific model, individuals working in exporting sectors should benefit since their wages increase. Similarly, the "Stolper-Samuelson" model predicts that workers employed in the sectors where a country has a comparative advantage experience an increase of their wages. Figure 5 shows the revealed comparative advantage index for Egypt. The latter has a high comparative advantage in non-metallic products, metals, textiles, and garments. Individuals working these sectors should experience an increase in their wages once trade is facilitated or liberalized.

Figure 5: Revealed Comparative Advantage in Egypt

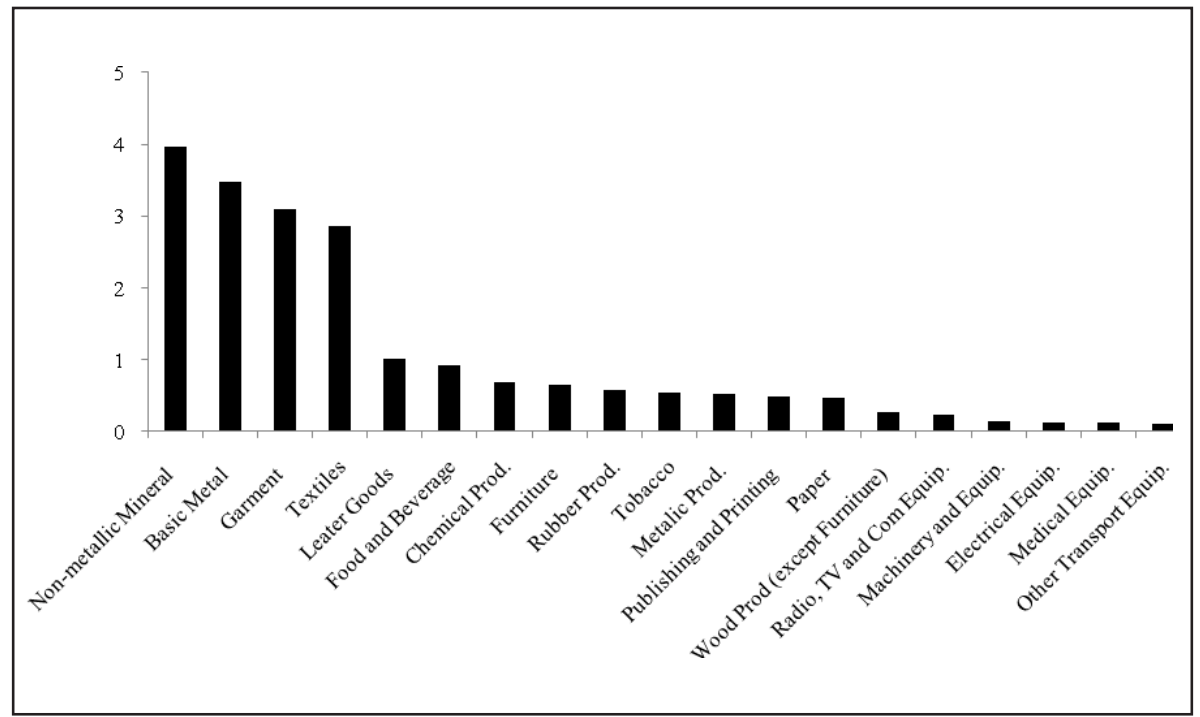

Source: Constructed by the author from Trade and Production.

Note: Figures show the revealed comparative advantage index in Egypt computed as follows:

$$
R C A=\frac{\frac{X_{i j}}{\sum_{i} X_{j}}}{\frac{X_{i w}}{\sum_{i} X_{w}}} \text { where } X_{i j} \text { and } X_{i w} \text { are the values of country } j \text { 's exports of product } i \text { and }
$$

world exports of product $i$ and where $\sum_{i} X_{j}$ and $\sum_{i} X_{w}$ refer to the country $j$ 's total exports and world total exports. A value of less than unity implies that the country has a revealed comparative disadvantage in the product. If the index is higher than unity, the country has a revealed comparative advantage in the product. 
After analyzing trade policy issues, it is worth giving a brief idea about the Egyptian labor market in order to find the nexus between trade policies and inequality. Table 6 shows that, between 1998 and 2006, the share of individuals working in the manufacturing sector has increased from $7.7 \%$ to $8.7 \%$. Agriculture share increased also with a similar pattern as industry. Finally, being the most important employer in Egypt, the share of services has significantly increased from $26.4 \%$ to $36 \%$. Our focus will be only on the manufacturing sector because it has witnessed the most important liberalization during the last decade.

Table 6: Distribution of Labor in Different Sectors, 2006

\begin{tabular}{|l|c|c|}
\hline Economic Activity & $\mathbf{1 9 9 8}(\%)$ & $\mathbf{2 0 0 6}(\%)$ \\
\hline Agriculture and Fishing & 6.34 & 8.62 \\
\hline Mining, Manufacturing & 7.66 & 8.67 \\
\hline Construction & 2.75 & 3.76 \\
\hline Wholesale, Hotels, and Restaurants. & 6.53 & 10.87 \\
\hline Transportation, Storage and Communication & 2.85 & 3.94 \\
\hline Financial \& Business Activities & 0.95 & 1.75 \\
\hline Public Service & 13.29 & 15.73 \\
\hline Other Econ. Activities. & 2.48 & 1.73 \\
\hline Other Status (Unemployment, out of Labor Force) & 57.15 & 44.93 \\
\hline Total & 100 & 100 \\
\hline
\end{tabular}

Source: Constructed by the author from ELMPS, 2006.

Taking all those barriers into account, their effect should not be inconsequential on trade, employment, and therefore on wage disparity.

\section{Methodology}

\subsection{A One-Step Analysis: the Human Capital Model}

To directly assess the effect of trade policy on wage disparity, I use the human capital model (Mincer, 1974) to which different trade barriers are added. The natural logarithm of real hourly wage ${ }^{8} \log \left(w_{i g s}\right)$ of individual $i$ living in region $g$ and working in sector $S$ is regressed on

8 Hourly real wages are calculated as the sum of wages earned in the reference month from primary jobs, adjusted for average number of work days per month and average hours per day. 
individual characteristics (education attainment and experience), other dummies capturing some specific individual $f_{i}$ (membership in a trade union, working in the public sector or being a production worker), and regional $f_{g}$ characteristics and different trade policy variables (tariffs $\operatorname{Tar}_{s}$, non-tariff measures $N T M_{s}$, the AVEs of the time to export $\operatorname{Tim}_{s}$ and that to import $\operatorname{Tim}_{s}$ capturing the effect of red tape costs). It is also important to include industry indicators that control for non-observable industry characteristics $\alpha_{i \dot{s}}$. The coefficient on the industry dummy, the wage premium, captures the part of the variation in wages that cannot be explained by worker characteristics, but explained by the workers' industry affiliation.

$$
\begin{aligned}
& \log \left(w_{i g s}\right)=\beta_{1 i}+\beta_{2 i} \cdot X_{i}+\alpha_{i s} w p_{s}+\gamma_{t a r} \operatorname{Tar}_{s}+\gamma_{n t m} N T M_{s} \\
& +\gamma_{t m} \operatorname{Tim}_{s}+\gamma_{t x} \operatorname{Tim} X_{s}+\varepsilon_{i g s}
\end{aligned}
$$

with $\mathcal{E}_{\text {igs }}$ the discrepancy term.

\subsection{A Two-Step Analysis: The Wage Premia}

In order to determine the impact of different trade barriers on wage premia, we have to run first the previous model without including trade barriers in it and then retrieve industry effects to be explained by trade barriers in a later stage. In other words, my first step will be as follows:

$$
\log \left(w_{i g s}\right)=\beta_{1 i}+\beta_{2 i} \cdot X_{i}+\alpha_{i s} w p_{s}+\varepsilon_{i g s}
$$

As per the second step, according to Attanasio et al. (2004), 9 since industry wage premia $w p_{s}$ are obtained by filtering out the effects of observable worker characteristics, they are regressed on a vector of trade policy variables, namely tariffs $\operatorname{Tar}_{s}$, non-tariff measures $N T M_{s}$, the AVEs of time to export $\operatorname{Tim} X_{s}$ and that to import $\operatorname{Tim}_{s}$ as follows:

$$
\left(w p_{s}\right)=\eta_{s}+\eta_{t a r} \operatorname{Tar}_{s}+\eta_{n t m} N T M_{s}+\eta_{t m} \operatorname{Tim}_{s}+\eta_{t x} \operatorname{Tim} X_{s}+\varepsilon_{s}
$$

9 For more details about the wage premium estimation, see Gaston and Trefler (1994), Attanasio et al (2004), Dutta (2007), and Said and El Azzawi (2009) 
Therefore, it is possible to determine the effect of each barrier on the inter-industry wage premium. ${ }^{10}$

Before presenting the data and the results, it is worth mentioning that one could expect that workers in an industry with high tariffs, nontariff measures, or red tape impediments are paid less than workers with identical characteristics in an industry with low tariffs. Heavily protected industries that are less productive employ also less productive workers who should earn lower wages. Thus, trade reform affects industry-level productivity which in turn boosts wages in these sectors thanks to trade liberalization or facilitation.

\section{Data}

\subsection{Microeconomic Data: ELMPS 2006}

Data used in this study are obtained from different sources. First, regarding microeconomic data,the Egyptian Labor Market Panel Survey (ELMPS 2006) is used. The latter is a nationally-representative household survey that consists of a total of 8,349 households distributed as follows: a total of 3,684 households followed since the Egyptian Labor Market Survey 1998, 2,176 new households that split from these households and a refresher sample consisting of 2,498 households was also included to ensure that the data continue to be nationally-representative after the split of some households that were present in 1998 . Both surveys' questionnaires (Barssoum, 2007) are composed of three major sections: (I) a household questionnaire administered to the head of household or the head's spouse that contains information on basic demographic characteristics of household members, movement of household members in and out of the household since 1998, ownership of durable goods and assets, and housing conditions, (2) an individual questionnaire administered to

10 To remedy for the sensitivity of the estimated wage premia with respect to the omitted industry dummy, I follow Haisken-DeNew and Schmidt (1997) that have calculated the wage premia as deviations from an employment weighted mean as follows

$$
\left(w p_{s}^{*}\right)=[I-W] w p_{s}
$$

where $w p_{s}^{*}$ is the normalized wage differentials, $I$ is an identity matrix and $W$ is a matrix of industry employment weights with each element $w_{s}=\frac{n_{s}}{\sum_{s} n_{s}}$, where $n$ is the number of workers in industry $s$.

Thus, equation 3 is estimated using the normalized wage differentials not the estimated ones. 
the individual containing information on parental background, detailed education histories, activity status, job search and unemployment, detailed employment characteristics, a module on women's work, migration histories, job histories, time use, earnings, and fertility. (3) A household enterprise and income module that elicits information on all agricultural and non-agricultural enterprises operated by the household as well as all income sources, including remittances and transfers.

My sample is restricted to individuals who are in the working age, between 15 and 64 years old. Only those who are working in the manufacturing sector are taken into account with some $1, \mathrm{I} 76$ individuals distributed among 20 manufacturing sectors ${ }^{\mathrm{II}}$ as it is shown in Table $\mathrm{I}$.

\subsection{Macroeconomic Data: Trade Policy Variables}

Trade policy variables have different sources. First, tariff data come from the World Trade Organization Tariffs Profile based on the Egyptian customs authority data. Those figures are applied tariffs in 2005 at the 2 digits level.

Second, non-tariff measures come from the CEPII's" "Trade and Production" database that includes the frequency of many non-tariff barriers such as the frequency of quotas, sanitary and phytosanitary measures, technical barriers to trade, etc.

Finally, I use the AVEs of the administrative barriers that have been estimated in Zaki (2009) ${ }^{13}$ through a theoretical gravity model using the Doing Business dataset (World Bank, 2007). Those estimations are made for the time to export and to import using a bunch of administrative barriers, namely bureaucracy, internet, corruption, and geographical impediments (being landlocked or an island). This is why such AVEs can be perceived as an exhaustive measure of red tape costs.

11 Those sectors are: food and beverages, tobacco, textiles, garments, leather goods, wood products, paper, publishing, coke and petroleum, chemical products, rubber products, non-metallic substances, basic metal, metallic products, machinery and equipment, electrical equipment, radio and television, medical equipment, transport equipment, and furniture

12 Centre d'Etudes Prospectives et d'Informations Internationales. They are available on CEPII's website.

13 To estimate the tariff equivalent of non-tariff and administrative barriers, the methodology of Olarreaga et al (2009) has been used. 


\section{Results}

Results are organized in three parts. First, I will try to determine to what extent trade barriers differently affect males vs. females, urban vs. rural workers, and blue vs. white collar workers. Moreover, quantile regressions, that are more robust to large outliers, are run to assess the effect of trade policy on different wage quantiles. Second, the effect of trade barriers on wage premia and on employment will be discussed. Finally, some sensitivity analysis will be presented.

The human capital model (Mincer, 1974) performs quite well since the findings are consistent with the classical results of the Mincerian equation. Experience has a positive effect and experience squared has a negative effect on wages. The more an individual is educated (captured by the number of years of schooling), the higher he earns. Living outside Greater Cairo (rural and urban regions in upper and lower Egypt) reduces income significantly. This in turn shows to what extent geographical disparities are a crucial issue in Egypt. Being a member of a trade union is likely to increase the real hourly wage since firms may be willing to pay higher wages if there is a viable threat of collective action. By contrast, a production worker earns less than a non-production one since the coefficient associated with the fact of being a blue collar worker is negative and statistically significant. Finally, working in the public sector or being a female does not affect wages.

Moving to trade policy variables, tariffs and red tape costs have a negative impact on all workers as it is presented in Column I in Table 7. Workers in industries characterized by a high protection are paid less than workers with identical characteristics in an industry with low protection. Since tariffs and administrative barriers induce distortions on the market, they reduce the efficiency and the productivity of firms and thus reduce wages. This is why, once tariffs and red tape costs are eliminated, wages should increase. By contrast, non-tariff measures have a positive effect on all workers. This result is similar to what Jean and Nicoletti (2002) found for the effect of non-tariff barriers on relative wages in OECD countries. This can be explained by the fact that the lack of competition from imports due to high non-tariff barriers raises the demand for labor, which in turn raises wages. Column 2 shows that the interaction between being a female and the different barriers is also significant. Thus, females suffer more than males from trade protection. First, tariffs seem to have a highly significant and negative effect on females' wages. Moreover, and even more importantly, administrative barriers to trade, especially the time to export, have also a significant and negative effect on females. Column 3 
displays the effect on males only. ${ }^{14}$ While non-tariff measures do not affect males' wages, both tariffs and red tape costs have a negative impact on their wages.

As per the regional level, while rural workers are more affected only by tariffs and the time to export, urban ones bear the cost of protection arising from all the barriers because tariffs, non-tariff measures and red tape costs have a negative effect on their wages. Hence, trade facilitation or liberalization should make urban workers better-off. By contrast, given the fact that the majority of rural individuals are working in the agriculture sector where Egypt does not have a comparative advantage, once trade is opened, farmers should be negatively affected which increase the gap between rural and urban workers.

Table 7: Trade Policy and Wages by Gender

\begin{tabular}{|l|c|c|c|}
\hline & 1 & 2 & 3 \\
\hline & All & All & Males \\
\hline & Ln (Hr. Wage) & Ln (Hr. Wage) & Ln (Hr. Wage) \\
\hline Tariff & $-0.00701^{* * *}$ & 0.000610 & $-0.00593^{* * *}$ \\
\hline Non Tariff & $(0.000769)$ & $(0.00158)$ & $(0.000857)$ \\
\hline & $0.0922^{* * *}$ & 0.0814 & $-2.49 \mathrm{e}-05$ \\
\hline AVE Time Exp & $(0.0198)$ & $(0.0492)$ & $(0.0174)$ \\
\hline & $-0.0118^{* * *}$ & $-0.00640^{* *}$ & $-0.00843^{* * *}$ \\
\hline AVE Time Imp & $(0.00240)$ & $(0.00241)$ & $(0.00182)$ \\
\hline & $-0.00376^{* * *}$ & $-0.00322^{*}$ & $-0.00521^{* * *}$ \\
\hline Public & $(0.000392)$ & $(0.00156)$ & $(0.000459)$ \\
\hline & 0.0211 & 0.0204 & 0.00537 \\
\hline Experience & $(0.0416)$ & $(0.0432)$ & $(0.0441)$ \\
\hline & $0.0370^{* * *}$ & $0.0368^{* * *}$ & $0.0360^{* * *}$ \\
\hline Experience2. & $(0.00577)$ & $(0.00557)$ & $(0.00624)$ \\
\hline & $-0.000406^{* * *}$ & $-0.000395^{* * *}$ & $-0.000377^{* *}$ \\
\hline Years of Schooling & $(0.000132)$ & $(0.000128)$ & $(0.000138)$ \\
\hline & $0.0261^{* * *}$ & $0.0277^{* * *}$ & $0.0279^{* * *}$ \\
\hline Trade Union & $(0.00603)$ & $(0.00590)$ & $(0.00663)$ \\
\hline & $0.394^{* * *}$ & $0.390^{* * *}$ & $0.372^{* * *}$ \\
\hline Not Cairo & $(0.0512)$ & $(0.0501)$ & $(0.0624)$ \\
\hline & $-0.120^{* * *}$ & $-0.122^{* * *}$ & $-0.131^{* * *}$ \\
\hline Blue Collar & $(0.0427)$ & $(0.0424)$ & $(0.0433)$ \\
\hline & $-0.133^{* * *}$ & $-0.131^{* *}$ & $-0.158^{* * *}$ \\
\hline
\end{tabular}

continued $\bullet$

14 I run the regressions on males only since the number of females in my dataset is quite small (around 150 women). 


\begin{tabular}{|l|c|c|c|}
\hline & $(0.0461)$ & $(0.0466)$ & $(0.0540)$ \\
\hline Female & -0.166 & 0.455 & \\
\hline & $(0.132)$ & $(0.307)$ & \\
\hline Female*AVETE & & $-0.0525^{* * *}$ & \\
\hline Female*AVETM & & $(0.0148)$ & \\
\hline & & -0.00413 & \\
\hline Female*Tariff & & $(0.0114)$ & \\
\hline & & $-0.0329^{* * *}$ & \\
\hline Female*NTB & & $(0.00769)$ & \\
\hline & & $0.542^{* *}$ & \\
\hline Constant & & $(0.220)$ & \\
\hline & $0.295^{* * *}$ & 0.120 & $0.320^{* *}$ \\
\hline Industry Dummies & $(0.0943)$ & $(0.100)$ & $(0.124)$ \\
\hline Observations & YES & YES & YES \\
\hline R-squared & 1176 & 1176 & 1026 \\
\hline
\end{tabular}

Notes: (i.)Standard errors in parentheses.

(ii.)Standard errors are clustered by industries.

(iii.) ${ }^{* * *},{ }^{* *}$ and ${ }^{*}$ represent respectively statistical significance at the $1 \%, 5 \%$ and $10 \%$ levels.

Table 8: Trade Policy and Wages by Region, 2006

\begin{tabular}{|l|c|c|}
\hline & 1 & 2 \\
\hline & Urban & Rural \\
\hline & Ln (Hr. Wage) & Ln (Hr. Wage) \\
\hline Tariff & $-0.00613^{* * *}$ & $-0.0164^{* * *}$ \\
\hline Non Tariff & $(0.00111)$ & $(0.00430)$ \\
\hline & $-0.0652^{* *}$ & 0.164 \\
\hline AVE Time Exp & $(0.0260)$ & $(0.140)$ \\
\hline & $-0.00472^{* * *}$ & $-0.0171^{* * *}$ \\
\hline AVE Time Imp & $(0.00157)$ & $(0.00202)$ \\
\hline & $-0.00729^{* * *}$ & -0.00227 \\
\hline Public & $(0.000722)$ & $(0.00340)$ \\
\hline & -0.0548 & $0.125^{*}$ \\
\hline Experience & $(0.0433)$ & $(0.0647)$ \\
\hline & $0.0515^{* * *}$ & $0.0197^{* *}$ \\
\hline Experience2 & $(0.00726)$ & $(0.00882)$ \\
\hline & $-0.000604^{* * *}$ & -0.000179 \\
\hline
\end{tabular}




\begin{tabular}{|l|c|c|}
\hline Years of Schooling & $0.0421^{* * *}$ & 0.00774 \\
\hline & $(0.00574)$ & $(0.00782)$ \\
\hline Trade Union & $0.386^{* * *}$ & $0.380^{* *}$ \\
\hline & $(0.0761)$ & $(0.132)$ \\
\hline Blue Collar & -0.0275 & $-0.281^{* * *}$ \\
\hline & $(0.0415)$ & $(0.0827)$ \\
\hline Female & $-0.302^{* * *}$ & 0.112 \\
\hline & $(0.0870)$ & $(0.340)$ \\
\hline Constant & -0.0498 & $0.654^{* *}$ \\
\hline & $(0.0991)$ & $(0.229)$ \\
\hline Industry Dummies & YES & YES \\
\hline Observations & 777 & 399 \\
\hline R-squared & 0.403 & 0.186 \\
\hline
\end{tabular}

Notes: (i.)Standard errors in parentheses.

(ii.)Standard errors are clustered by industries.

(iii.) ${ }^{* * *},{ }^{* *}$ and ${ }^{*}$ represent respectively statistical significance at the $1 \%, 5 \%$ and $10 \%$ levels.

Turning to the effect of different barriers on blue vs. white collar workers, Table 9 reveals that the former are much more affected by all trade barriers than the latter. Non-tariff measures and red tape barriers seem to be more onerous than tariffs for unskilled workers as they have a higher negative impact on their wages. This is in line with the sectors where Egypt has a comparative advantage and that are mainly intensive in blue collar jobs. Therefore, when trade is liberalized or facilitated, these sectors must expand, demand for blue collar workers will increase and consequently their wages.

It is important to notice that tariffs have a negative impact on white collar workers. More protected industries should witness less wages with respect to more opened ones. The link is as follows: the more the industry is open, the more firms will be productive to be able to export and to face fierce competition. Therefore they will hire skilled workers and their wages should increase. Such a result is consistent with the literature since it was stated that the increase in the skill premium was primarily driven by skilled-biased technological change after periods of trade liberalization and the increased foreign competition to which the trade reform exposed domestic producers.

Table 9 shows also that experience and education matter more for white collar workers than for blue collared ones. This is explained by the skills that are acquired through education and on-the-job-training and that are required by highly-qualified occupations (such as managers, clerical, etc.). The membership in a trade union increases wages for both of the two groups. 
Table 9: Trade Policy and Wages by Qualification, 2006

\begin{tabular}{|c|c|c|}
\hline & 1 & 2 \\
\hline & Blue Collar & White Collar \\
\hline & Ln (Hr. Wage) & Ln (Hr. Wage) \\
\hline \multirow[t]{2}{*}{ Tariff } & $-0.0182^{* * *}$ & $-0.00781^{* *}$ \\
\hline & $(0.000832)$ & $(0.00318)$ \\
\hline \multirow[t]{2}{*}{ Non Tariff } & $-0.124^{* *}$ & -0.0403 \\
\hline & $(0.0446)$ & $(0.0549)$ \\
\hline \multirow[t]{2}{*}{ AVE Time Exp } & $-0.0203^{* * *}$ & -0.00137 \\
\hline & $(0.00233)$ & $(0.00158)$ \\
\hline \multirow[t]{2}{*}{ AVE Time Imp } & $-0.0132^{* * *}$ & 0.00425 \\
\hline & $(0.000771)$ & $(0.00275)$ \\
\hline \multirow[t]{2}{*}{ Public } & $0.0962^{* * *}$ & -0.0518 \\
\hline & $(0.0277)$ & $(0.0804)$ \\
\hline \multirow[t]{2}{*}{ Experience } & $0.0300^{* * *}$ & $0.0570^{* * *}$ \\
\hline & $(0.00610)$ & $(0.0154)$ \\
\hline \multirow[t]{2}{*}{ Experience2 } & $-0.000302^{* *}$ & $-0.000796^{*}$ \\
\hline & $(0.000139)$ & $(0.000399)$ \\
\hline \multirow[t]{2}{*}{ Years of Schooling } & $0.0145^{* * *}$ & $0.0562^{* * *}$ \\
\hline & $(0.00426)$ & $(0.0130)$ \\
\hline \multirow[t]{2}{*}{ Trade Union } & $0.371^{* * *}$ & $0.316^{* * *}$ \\
\hline & $(0.0598)$ & $(0.0968)$ \\
\hline \multirow[t]{2}{*}{ Not Cairo } & $-0.151^{* * *}$ & -0.0619 \\
\hline & $(0.0503)$ & $(0.0671)$ \\
\hline \multirow[t]{2}{*}{ Female } & -0.147 & -0.256 \\
\hline & $(0.173)$ & $(0.165)$ \\
\hline \multirow[t]{2}{*}{ Constant } & $0.771^{* * *}$ & -0.273 \\
\hline & $(0.0869)$ & $(0.291)$ \\
\hline Industry Dummies & YES & YES \\
\hline Observations & 824 & 352 \\
\hline R-squared & 0.222 & 0.367 \\
\hline
\end{tabular}

Notes: (i.)Standard errors in parentheses.

(ii.)Standard errors are clustered by industries.

(iii.) ${ }^{* * *},{ }^{* *}$ and ${ }^{*}$ represent respectively statistical significance at the $1 \%, 5 \%$ and $10 \%$ levels.

Finally, in order to have a better investigation of the effect on skilled workers, quantile regressions should be observed since they provide a more precise picture of the wage distribution in the sample. Workers in the highest quantile ( $9 \mathrm{O}^{\text {th }}$ ) are affected only by tariffs. This confirms the result I have obtained for white collar workers that are only impacted by tariffs. Workers in the other quantiles are affected by either non-tariff measures or red tape costs or both of them. Concerning non-tariff measures, the 
higher the quantile, the higher the coefficient as they are-0.13, -0.I8, -0.25 and -0.24 for the $\mathrm{IO}^{\text {th }}, 25^{\text {th }}, 5 \mathrm{O}^{\text {th }}$, and $75^{\text {th }}$ quantiles respectively. In addition, the time to export is highly significant for the $75^{\text {th }}$ and the $90^{\text {th }}$ quantiles. Such a point proves that Egypt has to consider those implicit barriers to trade because they have a more important effect on wages. Finally, the coefficients of regional dummies are also negative and significant showing that an individual working in upper or lower Egypt earns less than the one working in Cairo with the same characteristics.

Table 10: Trade Policy and Wages by Quantiles, 2006

\begin{tabular}{|c|c|c|c|c|c|}
\hline & 10th & 25th & 50th & 75th & 90th \\
\hline & Ln (Hr. Wage) & Ln (Hr. Wage) & Ln (Hr. Wage) & Ln (Hr. Wage) & Ln (Hr. Wage) \\
\hline \multirow[t]{2}{*}{ Tariff } & 0.00212 & 0.00120 & $3.28 \mathrm{e}-05$ & -0.00555 & $-0.0147^{* *}$ \\
\hline & $(0.00422)$ & $(0.00296)$ & $(0.00407)$ & $(0.00349)$ & $(0.00738)$ \\
\hline \multirow[t]{2}{*}{ Non Tariff } & $-0.134^{*}$ & $-0.182^{* *}$ & $-0.255^{* * *}$ & $-0.237^{* * *}$ & 0.0207 \\
\hline & $(0.0737)$ & $(0.0747)$ & $(0.0732)$ & $(0.0627)$ & $(0.136)$ \\
\hline \multirow[t]{2}{*}{ AVE Time Exp } & -0.00436 & $-0.00972^{* *}$ & $-0.00976^{* * *}$ & $-0.0173^{* * *}$ & $-0.0377^{* * *}$ \\
\hline & $(0.00570)$ & $(0.00473)$ & $(0.00378)$ & $(0.00474)$ & $(0.00961)$ \\
\hline \multirow[t]{2}{*}{ AVE Time Imp } & -0.00564 & -0.00134 & $-0.00599^{*}$ & $-0.00909^{* * *}$ & 0.00374 \\
\hline & $(0.00503)$ & $(0.00304)$ & $(0.00341)$ & $(0.00273)$ & $(0.00653)$ \\
\hline \multirow[t]{2}{*}{ Public } & 0.0261 & 0.0484 & -0.000850 & -0.00114 & 0.0870 \\
\hline & $(0.0671)$ & $(0.0640)$ & $(0.0577)$ & $(0.0598)$ & $(0.119)$ \\
\hline \multirow[t]{2}{*}{ Experience } & $0.0443^{* * *}$ & $0.0412^{* * *}$ & $0.0436^{* * *}$ & $0.0406^{* * *}$ & $0.0323^{* * *}$ \\
\hline & $(0.00880)$ & $(0.00683)$ & $(0.00499)$ & $(0.00498)$ & $(0.00889)$ \\
\hline \multirow[t]{2}{*}{ Experience2. } & $-0.000648^{* * *}$ & $-0.000540^{* * *}$ & $-0.000580^{* * * *}$ & $-0.000480^{* * * *}$ & -0.000224 \\
\hline & $(0.000213)$ & $(0.000181)$ & $(0.000121)$ & $(9.26 \mathrm{e}-05)$ & $(0.000182)$ \\
\hline \multirow[t]{2}{*}{ Years of School } & $0.0265^{* * *}$ & $0.0211^{* * *}$ & $0.0235^{* * *}$ & $0.0277^{* * *}$ & $0.0341^{* * *}$ \\
\hline & $(0.00697)$ & $(0.00587)$ & $(0.00547)$ & $(0.00568)$ & $(0.00893)$ \\
\hline \multirow[t]{2}{*}{ Trade Union } & $0.250^{* * *}$ & $0.318^{* * *}$ & $0.332^{* * *}$ & $0.374^{* * *}$ & $0.392^{* *}$ \\
\hline & $(0.0725)$ & $(0.0643)$ & $(0.0476)$ & $(0.0494)$ & $(0.200)$ \\
\hline \multirow[t]{2}{*}{ Not Cairo } & $-0.127^{* *}$ & -0.0700 & -0.0434 & $-0.0728^{*}$ & $-0.253^{*}$ \\
\hline & $(0.0505)$ & $(0.0498)$ & $(0.0533)$ & $(0.0397)$ & $(0.132)$ \\
\hline \multirow[t]{2}{*}{ Prod. Work } & $-0.170^{*}$ & $-0.181^{* * *}$ & $-0.173^{* * *}$ & $-0.132^{* *}$ & $-0.280^{*}$ \\
\hline & $(0.0936)$ & $(0.0653)$ & $(0.0385)$ & $(0.0601)$ & $(0.170)$ \\
\hline \multirow[t]{2}{*}{ Female } & $-0.325^{* * *}$ & $-0.309^{* * *}$ & $-0.365^{* * *}$ & $-0.290^{* * *}$ & -0.213 \\
\hline & $(0.0983)$ & $(0.0892)$ & $(0.0600)$ & $(0.0600)$ & $(0.406)$ \\
\hline \multirow[t]{2}{*}{ Constant } & $-0.336^{* *}$ & -0.0113 & $0.385^{* * *}$ & $0.828^{* * *}$ & $1.417^{* * *}$ \\
\hline & $(0.160)$ & $(0.143)$ & $(0.0836)$ & $(0.0987)$ & $(0.360)$ \\
\hline Observations & 1176 & 1176 & 1176 & 1176 & 1176 \\
\hline
\end{tabular}

Notes: (i.)Standard errors in parentheses.

(ii.) ${ }^{* * *},{ }^{* *}$ and ${ }^{*}$ represent respectively statistical significance at the $1 \%, 5 \%$ and $10 \%$ levels. 
To conclude, it is worth mentioning that non-tariff measures as well as red tape barriers have a higher impact than classic tariffs on the wages of females, urban workers, and blue collar workers. Therefore, the elimination of such barriers will primarily benefit those categories.

Moving to the wage premia, as it is shown in Table II, tariffs and the time to export have a significantly negative effect on the wage premium. The time to import is not significant. This implies that increasing protection in a particular sector reduces wages in that sector. In other words, more trade liberalization and facilitation mean higher wages. Recall that those industry wage premia are conditioned on workers characteristics in the first stage, therefore, the relationship between different barriers and wage premia are not driven by observable differences in workers composition.

Table 11: Trade Policy and Wage Premium, 2006

\begin{tabular}{|l|c|l|c|}
\hline \multicolumn{2}{|c|}{ First step } & \multicolumn{2}{c|}{ Second step } \\
\hline & Ln (Wage) & & Wage Premium \\
\hline Public & 0.0226 & Tariff & $-0.0117^{*}$ \\
\hline & $(0.0408)$ & & $(0.00586)$ \\
\hline Experience & $0.0367^{* * *}$ & Time to Imp. & -0.000729 \\
\hline & $(0.00571)$ & & $(0.00373)$ \\
\hline Experience Sq. & $-0.000403^{* * *}$ & Time to Exp. & $-0.0192^{* *}$ \\
\hline & $(0.000131)$ & & $(0.00761)$ \\
\hline Years of Schooling & $0.0260^{* * *}$ & Non Tariff & 0.0730 \\
\hline & $(0.00599)$ & & $(0.111)$ \\
\hline Trade Union & $0.398^{* * *}$ & & \\
\hline & $(0.0500)$ & & \\
\hline Not Cairo & $-0.119^{* *}$ & & \\
\hline & $(0.0418)$ & & \\
\hline Blue Collar & $-0.131^{* * * *}$ & & \\
\hline & $(0.0454)$ & & \\
\hline Female & -0.167 & & 0.379 \\
\hline & $(0.132)$ & & $0.269^{*}$ \\
\hline Constant & $0.189^{* *}$ & Constant & \\
\hline & $(0.0898)$ & & \\
\hline Observations & 1176 & Observations & \\
\hline R-squared & 0.322 & R-squared & \\
\hline
\end{tabular}

Notes: (i.)Robust standard errors in parentheses.

(ii.) ${ }^{* * *},{ }^{* *}$ and ${ }^{*}$ represent respectively statistical significance at the $1 \%, 5 \%$ and $10 \%$ levels. 
Finally, Table I2 presents the effect on employment. It indicates that the share of skilled workers in each industry is inversely related to tariffs showing that industries with larger tariff reductions experienced more rapid skilled-biased technological change, as measured by the proportion of skilled workers. This is consistent with the "defensive innovation": firms in sectors facing intensified import competition look for new methods of production that economize on unskilled labor (Thoenig and Verdier, 2003). Such a result confirms the fact that skilled workers are the most negatively affected by trade barriers. By contrast, unskilled workers are more affected by the time to export. These findings confirm the previous ones regarding blue vs. white collar workers.

Table 12: Trade Policy and Employment, 2006

\begin{tabular}{|l|c|c|c|c|c|c|c|}
\hline & $\begin{array}{c}\text { Shr. of } \\
\text { Emp. }\end{array}$ & $\begin{array}{c}\text { Shr. of } \\
\text { Rural }\end{array}$ & $\begin{array}{c}\text { Shr. of } \\
\text { Urban }\end{array}$ & $\begin{array}{c}\text { Shr. of } \\
\text { Males }\end{array}$ & $\begin{array}{c}\text { Shr. of } \\
\text { Females }\end{array}$ & $\begin{array}{c}\text { Shr. of } \\
\text { Unskilled }\end{array}$ & $\begin{array}{c}\text { Shr. of } \\
\text { Skilled }\end{array}$ \\
\hline Tariff & -0.00134 & -0.00227 & -0.000855 & -0.00157 & 0.000285 & -0.000733 & $-0.00309^{*}$ \\
\hline & $(0.00161)$ & $(0.00229)$ & $(0.00144)$ & $(0.00182)$ & $(0.00218)$ & $(0.00177)$ & $(0.00161)$ \\
\hline Time to Imp. & 0.00196 & 0.00317 & 0.00133 & 0.00181 & 0.00293 & 0.00233 & 0.000863 \\
\hline & $(0.00137)$ & $(0.00195)$ & $(0.00123)$ & $(0.00154)$ & $(0.00185)$ & $(0.00151)$ & $(0.00137)$ \\
\hline Time to Exp. & $-0.00439^{*}$ & $-0.00638^{*}$ & -0.00338 & -0.00410 & $-0.00643^{* *}$ & $-0.00503^{*}$ & -0.00256 \\
\hline & $(0.00223)$ & $(0.00317)$ & $(0.00199)$ & $(0.00251)$ & $(0.00300)$ & $(0.00245)$ & $(0.00223)$ \\
\hline Non-Tariff & $0.117^{* *}$ & $0.124^{*}$ & $0.113^{* * *}$ & $0.0977^{*}$ & $0.249^{* * *}$ & $0.111^{* *}$ & $0.135^{* * *}$ \\
\hline & $(0.0420)$ & $(0.0597)$ & $(0.0375)$ & $(0.0473)$ & $(0.0566)$ & $(0.0461)$ & $(0.0420)$ \\
\hline Constant & $0.0516^{*}$ & 0.0634 & $0.0455^{*}$ & $0.0582^{*}$ & 0.00636 & 0.0463 & $0.0669^{* *}$ \\
\hline & $(0.0272)$ & $(0.0387)$ & $(0.0243)$ & $(0.0307)$ & $(0.0367)$ & $(0.0299)$ & $(0.0272)$ \\
\hline Observations & 20 & 20 & 20 & 20 & 20 & 20 & 20 \\
\hline R-squared & 0.425 & 0.322 & 0.465 & 0.276 & 0.709 & 0.440 & 0.434 \\
\hline
\end{tabular}

Notes: (i.)Robust standard errors in parentheses.

(ii.) ${ }^{* * *},{ }^{* *}$ and ${ }^{*}$ represent respectively statistical significance at the $1 \%, 5 \%$ and $10 \%$ levels.

Whereas the time to import does not affect any type of employment, that to export seems to have a negative and significant effect on all workers, females, rural, and unskilled workers. Non-tariff barriers have a highly positive and statistically significant effect on employment pointing out the fact that such barriers seem to protect workers from foreign competition and therefore there employment.

Tables I3, I4 and I5 display some robustness checks for my results. First, the wage coming from all jobs is used as a dependant variable instead of the one coming from the primary job. It turns out that results remain the same (Tables I3) for different segments. 
Table 13: Robustness Check 1: Wages from all Jobs

\begin{tabular}{|c|c|c|c|c|c|c|c|}
\hline & All & All & Males & Urban & Rural & $\begin{array}{l}\text { Blue } \\
\text { Collar }\end{array}$ & $\begin{array}{l}\text { White } \\
\text { Collar }\end{array}$ \\
\hline \multirow[t]{2}{*}{ Tariff } & $-0.00691^{* * *}$ & 0.000954 & $-0.00579 * * *$ & $-0.00623^{* * *}$ & $-0.0158^{* * *}$ & $-0.0181^{* * *}$ & $-0.00748^{* *}$ \\
\hline & $(0.000770)$ & $(0.00156)$ & $(0.000857)$ & $(0.00110)$ & $(0.00438)$ & $(0.000841)$ & $(0.00317)$ \\
\hline \multirow[t]{2}{*}{ Non Tariff } & $0.0848^{* * *}$ & 0.0764 & -0.00807 & $-0.0581^{* * *}$ & 0.152 & $-0.127^{* * *}$ & -0.0448 \\
\hline & $(0.0196)$ & $(0.0475)$ & $(0.0177)$ & $(0.0263)$ & $(0.143)$ & $(0.0426)$ & $(0.0552)$ \\
\hline \multirow[t]{2}{*}{ AVE Time Exp } & $-0.0116^{* * *}$ & $-0.00612^{* *}$ & $-0.00822^{* * *}$ & $-0.00518^{* * *}$ & $-0.0164^{* * *}$ & $-0.0205^{* * *}$ & -0.000829 \\
\hline & $(0.00237)$ & $(0.00239)$ & $(0.00178)$ & $(0.00157)$ & $(0.00200)$ & $(0.00232)$ & $(0.00159)$ \\
\hline \multirow[t]{2}{*}{ AVE Time Imp } & $-0.00384^{* * *}$ & $-0.00322^{* *}$ & $-0.00530^{* * *}$ & $-0.00713^{* * *}$ & -0.00247 & $-0.0131^{* * *}$ & 0.00391 \\
\hline & $(0.000387)$ & $(0.00150)$ & $(0.000457)$ & $(0.000722)$ & $(0.00348)$ & $(0.000741)$ & $(0.00270)$ \\
\hline \multirow[t]{2}{*}{ Public } & 0.0230 & 0.0222 & 0.00734 & -0.0537 & $0.129^{*}$ & $0.103^{* * *}$ & -0.0548 \\
\hline & $(0.0410)$ & $(0.0425)$ & $(0.0444)$ & $(0.0433)$ & $(0.0656)$ & $(0.0296)$ & $(0.0806)$ \\
\hline \multirow[t]{2}{*}{ Experience } & $0.0361^{* * *}$ & $0.0360^{* * *}$ & $0.0350^{* * *}$ & $0.0513^{* * *}$ & $0.0181^{*}$ & $0.0295^{* * * *}$ & $0.0550^{* * *}$ \\
\hline & $(0.00581)$ & $(0.00562)$ & $(0.00621)$ & $(0.00723)$ & $(0.00909)$ & $(0.00603)$ & $(0.0151)$ \\
\hline \multirow[t]{2}{*}{ Experience2 } & $-0.00039^{* * *}$ & $-0.00038^{* * *}$ & $-0.000357^{* *}$ & $-0.00060 * * *$ & -0.000147 & $-0.00029^{* *}$ & $-0.000752^{*}$ \\
\hline & $(0.000132)$ & $(0.000128)$ & $(0.000136)$ & $(0.000194)$ & $(0.000187)$ & $(0.000138)$ & $(0.000393)$ \\
\hline \multirow[t]{2}{*}{ Years of School } & $0.0258^{* * *}$ & $0.0274^{* * *}$ & $0.0276^{* * *}$ & $0.0424^{* * *}$ & 0.00669 & $0.0138^{* * *}$ & $0.0568^{* * *}$ \\
\hline & $(0.00619)$ & $(0.00603)$ & $(0.00680)$ & $(0.00564)$ & $(0.00793)$ & $(0.00436)$ & $(0.0127)$ \\
\hline \multirow[t]{2}{*}{ Trade Union } & $0.396 * * *$ & $0.392^{* * *}$ & $0.375^{* * *}$ & $0.389^{* * *}$ & $0.379^{* *}$ & $0.371^{* * *}$ & $0.317^{* * *}$ \\
\hline & $(0.0511)$ & $(0.0500)$ & $(0.0612)$ & $(0.0756)$ & $(0.136)$ & $(0.0599)$ & $(0.0968)$ \\
\hline \multirow[t]{2}{*}{ Not Cairo } & $-0.116^{* *}$ & $-0.118^{* *}$ & $-0.126^{* * *}$ & & & $-0.151^{* * *}$ & -0.0490 \\
\hline & $(0.0421)$ & $(0.0420)$ & $(0.0424)$ & & & $(0.0500)$ & $(0.0634)$ \\
\hline \multirow[t]{2}{*}{ Blue Collar } & $-0.136^{* *}$ & $-0.134^{* *}$ & $-0.161^{* * *}$ & -0.0211 & $-0.295^{* * *}$ & & \\
\hline & $(0.0476)$ & $(0.0482)$ & $(0.0559)$ & $(0.0432)$ & $(0.0870)$ & & \\
\hline \multirow[t]{2}{*}{ Female } & -0.166 & 0.456 & & $-0.302^{* * *}$ & 0.113 & -0.146 & -0.257 \\
\hline & $(0.133)$ & $(0.307)$ & & $(0.0870)$ & $(0.343)$ & $(0.173)$ & $(0.165)$ \\
\hline \multirow[t]{2}{*}{ Fem*AVETE } & & $-0.0524^{* * *}$ & & & & & \\
\hline & & $(0.0147)$ & & & & & \\
\hline \multirow[t]{2}{*}{ Fem*AVE TM } & & -0.00445 & & & & & \\
\hline & & $(0.0113)$ & & & & & \\
\hline \multirow[t]{2}{*}{ Female*Tariff } & & $-0.0331^{* * *}$ & & & & & \\
\hline & & $(0.00766)$ & & & & & \\
\hline \multirow[t]{2}{*}{ Female*NTB } & & $0.549^{* *}$ & & & & & \\
\hline & & $(0.221)$ & & & & & \\
\hline \multirow[t]{2}{*}{ Constant } & $0.301^{* * *}$ & 0.120 & $0.327^{* *}$ & -0.0568 & $0.678^{* *}$ & $0.775 * * *$ & -0.279 \\
\hline & $(0.0991)$ & $(0.104)$ & $(0.130)$ & $(0.100)$ & $(0.239)$ & $(0.0851)$ & $(0.292)$ \\
\hline Ind. Dummies & YES & YES & YES & YES & YES & YES & YES \\
\hline Observations & 1176 & 1176 & 1027 & 777 & 399 & 824 & 352 \\
\hline R-squared & 0.319 & 0.331 & 0.325 & 0.405 & 0.184 & 0.222 & 0.369 \\
\hline
\end{tabular}

Notes: (i.) The dependent variable is the total wage coming from all the jobs.

(ii.) Robust standard errors in parentheses.

(iii.) ${ }^{* * *},{ }^{* *}$ and ${ }^{*}$ represent respectively statistical significance at the $1 \%, 5 \%$ and $10 \%$ levels. 
To control for trade shares, sector dummies are suppressed and export and import shares in total output are introduced. Table I 4 shows that the higher the export shares, the higher the negative effect of the ad valorem equivalent of the time to export on wages. In addition, the higher the import share, the higher the negative effects of tariffs on wages. This shows that the most exporting sectors and the most importing ones are the most affected by red tape costs and tariffs respectively.

Table 14: Robustness Check 2: Imports and Exports Shares

\begin{tabular}{|c|c|c|c|c|c|c|}
\hline & All & Males & Urban & Rural & $\begin{array}{l}\text { White } \\
\text { Collar }\end{array}$ & Blue Collar \\
\hline & $\begin{array}{l}\text { Ln (Hr. } \\
\text { Wage) }\end{array}$ & $\begin{array}{l}\text { Ln (Hr. } \\
\text { Wage) }\end{array}$ & $\begin{array}{l}\text { Ln (Hr. } \\
\text { Wage) }\end{array}$ & $\begin{array}{l}\text { Ln (Hr. } \\
\text { Wage) }\end{array}$ & $\begin{array}{l}\text { Ln (Hr. } \\
\text { Wage) }\end{array}$ & $\begin{array}{l}\text { Ln (Hr. } \\
\text { Wage) }\end{array}$ \\
\hline \multirow[t]{2}{*}{ Tariff } & $-0.00658^{* *}$ & $-0.00635^{* *}$ & -0.00544 & $-0.0168^{* *}$ & $-0.0182^{* *}$ & $-0.00863^{* *}$ \\
\hline & $(0.00282)$ & $(0.00274)$ & $(0.00340)$ & $(0.00586)$ & $(0.00723)$ & $(0.00375)$ \\
\hline \multirow[t]{2}{*}{ Non Tariff } & 0.00198 & 0.0141 & -0.0518 & 0.0956 & 0.0615 & -0.0436 \\
\hline & $(0.115)$ & $(0.119)$ & $(0.142)$ & $(0.155)$ & $(0.213)$ & $(0.133)$ \\
\hline \multirow[t]{2}{*}{ AVE Time Exp } & 0.00520 & 0.00277 & 0.0208 & -0.0272 & 0.0172 & -0.0252 \\
\hline & $(0.0127)$ & $(0.0125)$ & $(0.0151)$ & $(0.0205)$ & $(0.0231)$ & $(0.0205)$ \\
\hline \multirow[t]{2}{*}{ AVE Time Imp } & 0.00371 & 0.00326 & $-9.09 e-05$ & $0.0117^{* *}$ & 0.00742 & 0.00638 \\
\hline & $(0.00381)$ & $(0.00342)$ & $(0.00401)$ & $(0.00492)$ & $(0.00949)$ & $(0.00403)$ \\
\hline \multirow[t]{2}{*}{ Public } & 0.00621 & -0.000708 & -0.0311 & 0.0594 & -0.0304 & 0.0657 \\
\hline & $(0.0413)$ & $(0.0442)$ & $(0.0434)$ & $(0.0548)$ & $(0.0797)$ & $(0.0390)$ \\
\hline \multirow[t]{2}{*}{ Experience } & $0.0363^{* * *}$ & $0.0357^{* * *}$ & $0.0508^{* * *}$ & $0.0200^{* *}$ & $0.0551^{* * *}$ & $0.0298^{* * *}$ \\
\hline & $(0.00541)$ & $(0.00616)$ & $(0.00703)$ & $(0.00835)$ & $(0.0145)$ & $(0.00611)$ \\
\hline \multirow[t]{2}{*}{ Experience2 } & $-0.000377^{* * *}$ & $-0.000369^{* *}$ & $-0.000586^{* * *}$ & -0.000182 & $-0.000758^{*}$ & $-0.000284^{*}$ \\
\hline & $(0.000126)$ & $(0.000138)$ & $(0.000189)$ & $(0.000169)$ & $(0.000374)$ & $(0.000140)$ \\
\hline \multirow[t]{2}{*}{ Years of Schooling } & $0.0283^{* * *}$ & $0.0284^{* * * *}$ & $0.0424^{* * * *}$ & 0.00772 & $0.0585^{* * * *}$ & $0.0150^{* * * *}$ \\
\hline & $(0.00609)$ & $(0.00663)$ & $(0.00559)$ & $(0.00772)$ & $(0.0132)$ & $(0.00439)$ \\
\hline \multirow[t]{2}{*}{ Trade Union } & $0.395^{* * *}$ & $0.376^{* * *}$ & $0.393^{* * * *}$ & $0.331^{* * *}$ & $0.315^{* * *}$ & $0.360^{* * * *}$ \\
\hline & $(0.0477)$ & $(0.0610)$ & $(0.0726)$ & $(0.132)$ & $(0.0956)$ & $(0.0544)$ \\
\hline \multirow[t]{2}{*}{ Exp. Share } & $1.378^{* * *}$ & $1.339^{* * *}$ & $1.676^{* * *}$ & 0.646 & $1.889 * * *$ & $0.845^{* * *}$ \\
\hline & $(0.338)$ & $(0.275)$ & $(0.352)$ & $(0.521)$ & $(0.390)$ & $(0.343)$ \\
\hline \multirow[t]{2}{*}{ Imp. Share } & $0.0712^{* *}$ & $0.0728^{* * *}$ & $0.128^{* * *}$ & -0.0499 & -0.0437 & 0.0570 \\
\hline & $(0.0259)$ & $(0.0205)$ & $(0.0210)$ & $(0.0741)$ & $(0.261)$ & $(0.0417)$ \\
\hline \multirow[t]{2}{*}{ Exp. Sh*AVE TE } & $-0.0931^{* *}$ & -0.0710 & $-0.190^{* * *}$ & 0.0969 & -0.154 & $3.08 \mathrm{e}-05$ \\
\hline & $(0.0402)$ & $(0.0424)$ & $(0.0525)$ & $(0.0688)$ & $(0.102)$ & $(0.0776)$ \\
\hline \multirow[t]{2}{*}{ Imp. Sh* NTB } & 0.0116 & 0.0201 & -0.173 & 0.396 & -0.0716 & 0.430 \\
\hline & $(0.221)$ & $(0.222)$ & $(0.264)$ & $(0.348)$ & $(0.519)$ & $(0.354)$ \\
\hline \multirow[t]{2}{*}{ Imp. Sh* AVE TM } & 0.000687 & 0.00198 & $-0.00537^{*}$ & 0.00299 & $5.26 \mathrm{e}-05$ & 0.00648 \\
\hline & $(0.00332)$ & $(0.00320)$ & $(0.00300)$ & $(0.0126)$ & $(0.0199)$ & $(0.00964)$ \\
\hline Imp. Sh*Tariff & $-0.0105^{* *}$ & $-0.0107^{* * * *}$ & $-0.0195^{* * *}$ & 0.00973 & -0.00151 & -0.0107 \\
\hline
\end{tabular}




\begin{tabular}{|l|c|c|c|c|c|c|}
\hline & $(0.00427)$ & $(0.00366)$ & $(0.00357)$ & $(0.0137)$ & $(0.00480)$ & $(0.00855)$ \\
\hline Blue Collar & $-0.150^{* * *}$ & $-0.176^{* * *}$ & -0.0611 & $-0.280^{* * *}$ & & \\
\hline & $(0.0402)$ & $(0.0471)$ & $(0.0378)$ & $(0.0844)$ & & \\
\hline Not Cairo & $-0.132^{* * *}$ & $-0.136^{* * *}$ & & & -0.0818 & $-0.140^{* * *}$ \\
\hline & $(0.0444)$ & $(0.0443)$ & & & $(0.0637)$ & $(0.0473)$ \\
\hline Female & 0.349 & & $-0.300^{* * *}$ & 0.101 & -0.245 & -0.142 \\
\hline & $(0.364)$ & & $(0.0863)$ & $(0.333)$ & $(0.163)$ & $(0.171)$ \\
\hline Female*AVE TE & $-0.0471^{* *}$ & & & & & \\
\hline & $(0.0165)$ & & & & & \\
\hline Female*AVETM & -0.00266 & & & & & \\
\hline & $(0.0116)$ & & & & & \\
\hline Female*Tariff & $-0.0302^{* * *}$ & & & & & \\
\hline & $(0.00850)$ & & & & & \\
\hline Female*NTB & $0.576^{* *}$ & & & & & \\
\hline & $(0.235)$ & & & & & \\
\hline Constant & 0.0571 & 0.0837 & -0.264 & 0.375 & -0.464 & 0.214 \\
\hline & $(0.202)$ & $(0.207)$ & $(0.178)$ & $(0.261)$ & $(0.340)$ & $(0.165)$ \\
\hline $\begin{array}{l}\text { Industry } \\
\text { Dummies }\end{array}$ & $\mathrm{N} 0$ & $\mathrm{~N} 0$ & $\mathrm{~N} 0$ & $\mathrm{~N} 0$ & $\mathrm{~N} 0$ & N0 \\
\hline Observations & 1176 & 1026 & 777 & 399 & 352 & 824 \\
\hline R-squared & 0.318 & 0.315 & 0.389 & 0.165 & 0.344 & 0.206 \\
\hline
\end{tabular}

Notes: (i.)Robust standard errors in parentheses.

(ii.) ${ }^{* * *},{ }^{* *}$ and ${ }^{*}$ represent respectively statistical significance at the $1 \%, 5 \%$ and $10 \%$ levels.

Figure 6: Interacting Trade Shares and Trade Barriers: Time to Export

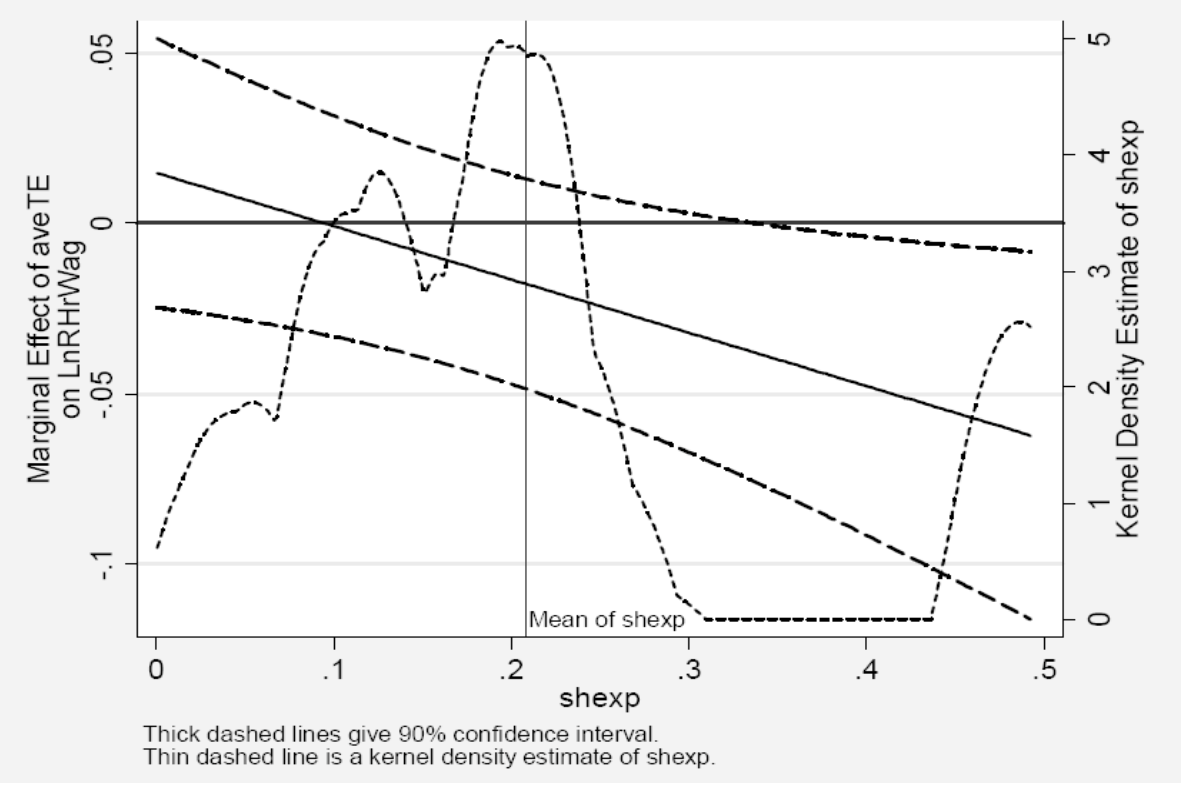

Source: Constructed by the author. 
Figure 7: Interacting Trade Shares and Trade Barriers: Tariffs

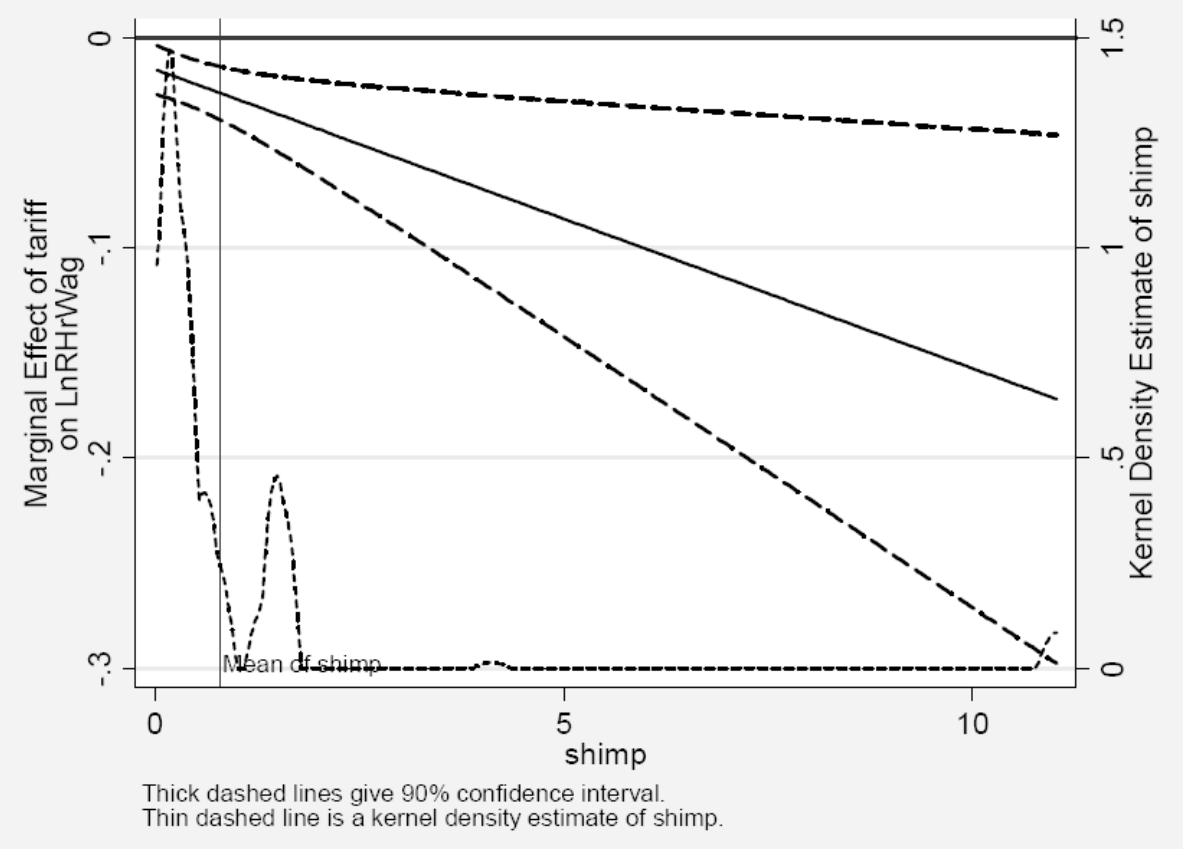

Source: Constructed by the author.

Finally, skilled and unskilled workers were previously distinguished according to their occupation. Here, they are differentiated on the basis of their education level..$^{15}$ As it is shown in Table 15 , unskilled workers (or blue collar workers) are more affected by all types of barriers.

Table 15: Robustness Check 3: By Education Level

\begin{tabular}{|l|c|c|}
\hline & Low Educ. & High Educ. \\
\hline & Ln (Hr. Wage) & Ln (Hr. Wage) \\
\hline Tariff & $-0.0141^{* * *}$ & -0.00362 \\
\hline & $(0.00107)$ & $(0.00213)$ \\
\hline Non Tariff & $-0.109^{* *}$ & 0.150 \\
\hline & $(0.0419)$ & $(0.123)$ \\
\hline AVE Time Exp & $-0.0109^{* * *}$ & -0.00862 \\
\hline & $(0.00268)$ & $(0.00502)$ \\
\hline AVE Time Imp & $-0.0108^{* * *}$ & $0.0174^{* * *}$ \\
\hline & $(0.000748)$ & $(0.00175)$ \\
\hline
\end{tabular}

continued $\bullet$

15 Skilled workers are those who have higher than intermediate level of education and unskilled ones have a lower than intermediate education. 


\begin{tabular}{|l|c|c|}
\hline Public & $0.103^{* * *}$ & -0.0151 \\
\hline & $(0.0347)$ & $(0.0933)$ \\
\hline Experience & $0.0347^{* * *}$ & 0.0481 \\
\hline & $(0.00579)$ & $(0.0289)$ \\
\hline Experience2 & $-0.000387^{* * *}$ & -0.000464 \\
\hline & $(0.000126)$ & $(0.000813)$ \\
\hline Years of Schooling & $0.0206^{* * *}$ & $0.0741^{* *}$ \\
\hline & $(0.00611)$ & $(0.0290)$ \\
\hline Trade Union & $0.325^{* * *}$ & $0.460^{* *}$ \\
\hline & $(0.0545)$ & $(0.179)$ \\
\hline Not Cairo & -0.0834 & $-0.213^{*}$ \\
\hline & $(0.0524)$ & $(0.102)$ \\
\hline Female & -0.123 & $-0.380^{* *}$ \\
\hline & $(0.151)$ & $(0.144)$ \\
\hline Industry Dummies & YES & YES \\
\hline Constant & $0.513^{* * *}$ & -0.861 \\
\hline & $(0.0970)$ & $(0.652)$ \\
\hline Observations & 974 & 202 \\
\hline R-squared & 0.246 & 0.443 \\
\hline
\end{tabular}

Notes: (i.)Robust standard errors in parentheses.

(ii.) ${ }^{* * *},{ }^{* *}$ and ${ }^{*}$ represent respectively statistical significance at the $1 \%, 5 \%$ and $10 \%$ levels

\section{Conclusions}

This paper proposes an empirical investigation of the effect of different trade barriers on wages in Egypt. The effect of trade barriers on wage disparity has been widely discussed at both empirical and public policy levels. This debate mainly dealt with traditional tariff barriers. Less attention has been attributed to other barriers such as non-tariff measures and red tape costs. However, these barriers, and in particular red tape costs, are more impeding than tariffs in developing countries. Thus, using a microeconomic dataset, I try to assess to what extent different trade barriers affected wage disparities and employment in Egypt. These disparities are studied in three dimensions: on gender (males vs. females), qualification (skilled vs. unskilled), and regional (urban vs. rural workers). My main findings show that both non-tariff measures and red tape barriers have a higher impact than traditional tariffs on wage disparity. Female, 
urban, and blue collar workers are more affected by such barriers. Finally, when the effects of observable worker characteristics are filtered out, it turns out that wage premia are negatively affected by all trade barriers.

From a policymaking standpoint, such a study points out to some crucial implications. First, since barriers associated with trade facilitation are a deadweight loss, all agents and sectors should gain from such a process. That is why developing countries must pursue reforms in order to eliminate non-official (border-related procedures) barriers that are less transparent. Second, since administrative barriers have a higher adverse effect on wage disparity than traditional tariffs, the government of Egypt should focus on trade facilitation rather than trade liberalization to boost trade, and consequently production, labor demand, and wages. Third, as Egypt has a comparative advantage in sectors that are highly intensive in blue collar workers, the government must put in place a policy aiming at liberalizing and developing these sectors in order to generate new employment opportunities and reducing unemployment among them. Providing technical training for these workers is crucial to increase their productivity in order to better face the fierce competition once the economy is more exposed to the rest of the world. Finally, for females in particular, since they are working in sectors characterized by a comparative advantage, the trade facilitation and liberalization of these sectors is likely to increase female employment.

The findings of this study suggest three potential areas for future research. First, it is worth mentioning that developing a theoretical model would be crucial in providing better insights into the trade facilitation effects on wage inequality. Moreover, it would be interesting to apply the same analysis for services and agriculture given the importance of the former and the high protection of the latter in Egypt. Last but not least, in order to determine the evolution of trade policy in Egypt, the panel dimension should be used. Clearly, this can be done once data for administrative and non-tariff barriers are available. 


\section{Acknowledgment}

I would like to thank Mona Said, Nadia Rocha, Ragui Assaad, and Lionel Fontagné. I am also grateful to Marcelo Olarreaga and Akiko Suwa Eisenmann for their important comments. I also thank participants at the University of Paris I Panthéon Sorbonne seminars and the Population Council workshop. All the relevant data and computation files are available upon request from the author. Any remaining errors are mine. 


\section{References}

Aguayo-Tellez, E., Airola, J., and Juhn, C. (2010) "Did Trade Liberalization Help Women? The Case of Mexico in the I99os," NBER Working Paper No. I6I95, July.

Artecona, R. and Cunningham, W. (2002) "Effects of Trade Liberalization on the Gender Wage Gap in Mexico," The World Bank, May.

Araújo, B., Bogliacino, F., and Vivarelli, M. (2009) "The Role of Skill Enhancing Trade in Brazil: Some Evidence from Microdata," IZA Discussion Paper No. 4213, June.

Assaad, R. (2007) "Labour supply, employment and unemployment in the Egyptian economy: 1988-2006." Population Council Working Paper O7OI.

Attanasio, O., Goldberg, P., and Pavcnik, N. (2004) "Trade Reforms and Wage Inequality in Colombia," Journal of Development Economics, 74 (2): $33 \mathrm{I}^{-}-66$.

Blom, A., Goldberg, P., Pavnick, N., and and Schady, N. (2004) "Trade Policy and Industry Wage Structure: Evidence from Brazil," World Bank Economic Review I8(3), pages 319-344, December.

Bantout, O. and Jean, S. (1998) Sensibilité des salaires relatifs aux chocs exogènes de commerce international et de progrès technique : une évaluation d'équilibre général", CEPII Working Paper, No 1998 - o9 Septembre.

Barssoum, G. (2007) "Egypt labour market panel survey 2006: Report on methodology and data collection." Economic research forum (ERF) working paper 0704 .

Becker, G. (I97I) The Economics of Discrimination, Ist ed. (Chicago: University of Chicago Press).

Caatay, N. (200I) "Trade, Gender and Poverty," United Nations Development Programme.

Dutta, P. (2007) "Trade Protection and Industry Wages in India," Industrial and Labor Relations Review 6o (2): 268-86.

El-Hamidi, F. (2008) "Trade liberalization, gender segmentation, and Wage Discrimination: Evidence from Egypt," Economic Research Forum Working Paper 4I4.

Feenstra, R. and Hanson, G. (200I) "Global Production Sharing and Rising Inequality: A Survey of Trade and Wages,” NBER Working Paper 8372, July.

Gaston, N. and Trefler, D. (1994) "Protection, Trade, and Wages: Evidence from U.S. Manufacturing," Industrial and Labor Relations Revierw 47 (4) (July): 574-93. 
Goh, C. and Javorcik, B. (2005) "Trade Protection and Industry Wage Structure in Poland," NBER Working Papers III43, National Bureau of Economic Research.

Goldberg, P. and Pavnick, N. (2007a) "The Effects of the Colombian Trade Liberalization on Urban Poverty," in Harrison, A. (ed) Globalization and Poverty, NBER and University Chicago Press 2007. pages 24I-290.

Goldberg, P. and Pavnick, N. (2007b) Distributional Effects of Globalization in Developing Countries," Fournal of Economic Literature, 45(I), pages 39-82, March.

Goldberg, P. and Pavcnik, N. (2004) Trade, Inequality, and Poverty: What Do We Know? Evidence from Recent Trade Liberalization Episodes in Developing Countries." Evidence from Recent Trade Liberalisation Episodes in Developing Countries. Paper prepared for the 2004 Brookings Trade Forum on "Globalization, Poverty and Inequality: What Do We Know? Where Are We Going?" Washington DC, May, 2004.

Haisken-DeNew, J. and Schmidt, C. (1997) "Inter-Industry and InterRegion Differentials: Mechanics and Interpretation," Revierw of Economics and Statistics, 79 (3), pages 5I6-2I.

Kee, H., Nicita, A. and Olarreaga, M. (2009) "Estimating Trade Restrictiveness Indices," Economic fournal, Royal Economic Society, vol. II9(534), pages I72-I99, OI.

Klein, C., Moser, C., and Urban, D. (2010) "The Contrinution of Trade to Wage Inequality: the Role of Skill, Gender and Nationality," NBER Working Paper Series, No. 15985, May.

Korayem, K. (I997) "Egypt's economic reform and structural adjustment (ERSAP),” ECES Working Paper I9, October.

Krugman, P. and Livas-Elizondo, R. (1996) "Trade Policy and the Third World Metropolis," Journal of Development Economics, Vol. 49, pages I37-I5O.

Meschi, E., Taymaz, E. and Vivarelli, M. (2009) "Trade, Technology and Skills: Evidence from Turkish Microdata," Jena Economic Research Papers, No. 2009097, November.

Milanovic, B and Squire, L. (2007) "Does Tariff Liberalization Increase Wage Inequality? Some Empirical Evidence," in "Globalization and Poverty." Edited by Ann Harrison, University of Chicago Press: Chicago, pages I43I82.

Mincer, J. (I974) Schooling, Experience and Earnings. Columbia University Press: New York.

Nicita, A. (2004) "Who benefited from trade liberalization in Mexico? Measuring the effects on household welfare," Policy Research Working Paper Series 3265, The World Bank. 
Paluzie, E. (200I) "Trade Policy and Regional Inequalities," Papers in Regional Sciences, No 80, pages 67-85.

Puga, D. (I999) "The Rise and Fall of Regional Inequalities," European Economic Review, No. 43, pages 303-334.

Puga, D. and Venables, A. (I999) "Agglomeration and Economic Development: Import Substitution vs. Trade Liberalization," Economic Journal, Royal Economic Society, Vol. Io9(455), pages 292-3II, April.

Ohlin, B. (I933) "Interregional and International Trade," Harvard University Press, Cambridge.

Redding S. and Venables A., (2004) "Economic Geography and International Inequality," Fournal of International Economics 62 (2004) 53-82.

Said, M. and El Azzawi, S. (2009) "Trade Liberalization, Inter-industry Wage Differentials and Job Quality in Egyptian Manufacturing," Gender and Work in The MENA Region Working Paper Series, Number 6, August.

Said, M. (2007) "The Fall and Rise of Earnings and Inequality in Egypt: New Evidence From the ELMPS, 2006," ERF Working Paper 0708.

Sébastien, J. and Nicoletti, G. (2002) "Product Market Regulation and Wage Premia in Europe and North America: An Empirical Investigation," OECD Economics Department Working Paper No. 318.

Sutton, J. (2002) "Rich Trades, Scarce Capabilities-Industrial Development Revisited," The Economic and Social Reviere, Economic and Social Studies, vol. 33(I), pages I-22.

Thoenig, M. and Verdier, T. (2003) "A Theory of Defensive Skill-Biased Innovation and Globalization," American Economic Reviere, American Economic Association, vol. 93(3), pages 709-728, June.

Topalova, P. (2005) "Trade Liberalization, Poverty and Inequality: Evidence From Indian Districts," NBER Working Papers No. II6I4.

United Nations Conference on Trade and Development (200I) "E-Commerce and Development Report," UNCTAD: Geneva.

Viner, J. (I93I) "Cost Curves and Supply Curves," Zeitschrift für Nationalokonomie, 3 (I93I), 23-46. Reprinted in AEA Readings in Price Theory (Allen and Unwin, London), I953.

World Bank, (I99I) "Egypt, alleviating poverty during structural adjustment," Washington, DC.

Zaki, C. (2009) "Does Trade Facilitation Matter in Bilateral Trade," CES Working Paper 2008. Ioo, December.

Zaki, C. (2008) "Making International Trade Easier: A Survey of the Trade Facilitation Effects," mimeo. 

